\title{
Inositol Adenophostin: Convergent Synthesis of a Potent Agonist of D-myo-Inositol 1,4,5-Trisphosphate Receptors
}

\author{
Xiangdong Su, Wolfgang Dohle, Stephen J. Mills, Joanna M. Watt, Ana M. Rossi, Colin W. Taylor,
} and Barry V. L. Potter*

Cite This: ACS Omega 2020, 5, 28793-28811

Read Online

\section{ACCESS | Lill Metrics \& More | 回 Article Recommendations ｜（） Supporting Information}

ABSTRACT: D-myo-Inositol 1,4,5-trisphosphate receptors $\left(\mathrm{IP}_{3} \mathrm{Rs}\right)$ are $\mathrm{Ca}^{2+}$ channels activated by the intracellular messenger inositol 1,4,5-trisphosphate $\left(\mathrm{IP}_{3}, \mathbf{1}\right)$. The glyconucleotide adenophostin $\mathrm{A}$ (AdA, 2) is a potent agonist of $\mathrm{IP}_{3}$ Rs. A recent synthesis of D-chiro-inositol adenophostin (InsAdA, 5) employed suitably protected chiral building blocks and replaced the D-glucose core by D-chiro-inositol. An alternative approach to fully chiral material is
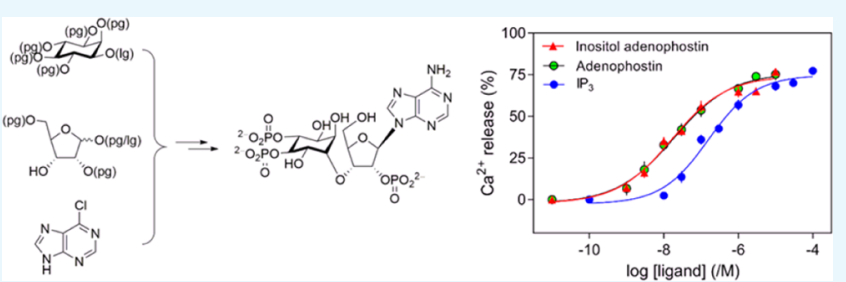
now reported using intrinsic sugar chirality to avoid early isomer resolution, involving the coupling of a protected and activated racemic myo-inositol derivative to a D-ribose derivative. Diastereoisomer separation was achieved after trans-isopropylidene group removal and the absolute ribose-inositol conjugate stereochemistry assigned with reference to the earlier synthesis. Optimization of stannylene-mediated regiospecific benzylation was explored using the model 1,2-O-isopropylidene-3,6-di-O-benzyl-myo-inositol and conditions successfully transferred to one conjugate diastereoisomer with 3:1 selectivity. However, only roughly 1:1 regiospecificity was achieved on the required diastereoisomer. The conjugate regioisomers of benzyl derivatives 39 and $\mathbf{4 0}$ were successfully separated and 39 was transformed subsequently to InsAdA after amination, pan-phosphorylation, and deprotection. InsAdA from this synthetic route bound with greater affinity than AdA to $\mathrm{IP}_{3} \mathrm{R} 1$ and was more potent in releasing $\mathrm{Ca}^{2+}$ from intracellular stores through $\mathrm{IP}_{3} \mathrm{Rs}$. It is the most potent full agonist of $\mathrm{IP}_{3} \mathrm{R} 1$ known and equipotent with material from the fully chiral synthetic route.

\section{INTRODUCTION}

Inositol 1,4,5-trisphosphate receptors ( $\left.\mathrm{IP}_{3} \mathrm{Rs}\right)$ are intracellular $\mathrm{Ca}^{2+}$ channels. In most animal cells, $\mathrm{IP}_{3} \mathrm{Rs}$ release $\mathrm{Ca}^{2+}$ from the endoplasmic reticulum (ER) in response to the many extracellular stimuli that evoke formation of D-myo-inositol 1,4,5-trisphosphate $\left(\mathrm{IP}_{3}, \mathbf{1}\right.$, Figure 1$) . \mathrm{IP}_{3} \mathrm{Rs}$ thereby generate $\mathrm{Ca}^{2+}$ signals that regulate diverse cellular processes. ${ }^{1} \mathrm{IP}_{3} \mathrm{R}$ activation is initiated by $\mathrm{IP}_{3}$ binding to the $\mathrm{IP}_{3}$-binding core (IBC, residues 224-604) of each subunit of the tetrameric receptor. ${ }^{2}$ The two domains ( $\alpha$ and $\beta$ ) of the IBC form a clamshaped structure, lined by conserved residues that coordinate $\mathrm{IP}_{3}$ (Figure 2a). ${ }^{3}$ The 4-phosphate of $\mathrm{IP}_{3}$ interacts primarily with IBC- $\beta$, whereas the 1 - and 5-phosphates interact predominantly with residues in IBC- $\alpha$. Interaction of the critical vicinal 4- and 5-phosphates ${ }^{4,5}$ with opposing sides of the clam allows $\mathrm{IP}_{3}$ to partially close the clam. ${ }^{6-8}$ This initial conformational change then propagates through putative $\mathrm{Ca}^{2+}$ binding sites to the pore, where the movement of occluding hydrophobic residues within the pore opens a path for $\mathrm{Ca}^{2+}$ to leak from the ER lumen to the cytosol. ${ }^{1,8}$

Although an extensive understanding of the structureactivity relationships (SARs) of $\mathrm{IP}_{3}$ analogues and other noninositol-based derivatives has been established, there is still much ongoing interest in the structure-based design of new ligands of $\mathrm{IP}_{3}$ Rs. $^{9-12}$ Adenophostin A (AdA, 2) and its acetate analogue, adenophostin $\mathrm{B}(\mathrm{AdB}, 3)$, are highly potent $\mathrm{IP}_{3} \mathrm{R}$ agonists isolated from Penicillium brevicompactum. ${ }^{13}$ Both compounds bind to $\mathrm{IP}_{3} \mathrm{Rs}$ with about tenfold greater affinity than $\mathrm{IP}_{3}$, and they stimulate $\mathrm{Ca}^{2+}$ release with about tenfold higher potency than $\mathrm{IP}_{3} \cdot{ }^{1414}$ These compounds and their analogues have elicited much synthetic and biological interest. $^{1,4,5}$

The vicinal 3",4"-bisphosphate motif in AdA resembles the critical 4,5-bisphosphate moiety in $\mathrm{IP}_{3}$. SAR considerations show that the $3^{\prime \prime}, 4^{\prime \prime}$-bisphosphates in AdA (Figure 5, red area), although not essential for $\mathrm{Ca}^{2+}$ release, ${ }^{5}$ are important since $3^{\prime \prime}$ dephospho-AdA (Figure 3, compound 6) is almost 10000 -fold less potent than AdA, and 4"-dephospho-AdA (Figure 3, compound 7) is inactive. ${ }^{5,18}$ Loss of the 6-OH group from $\mathrm{IP}_{3}$ causes a ca. 100 -fold decrease in potency. ${ }^{4}$ The 2 "-hydroxyl of AdA may partially mimic the 6-OH of $\mathrm{IP}_{3}$ since manno-AdA (Figure 3, compound 9), in which the $\mathrm{C} 2$ " configuration is inverted, is 5-10-fold less potent than AdA. ${ }^{10,14}$ The enhanced

Received: August 27, 2020

Accepted: October 8, 2020

Published: October 28, 2020 


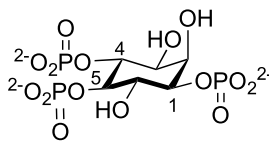

$1 \mathrm{IP}_{3}$

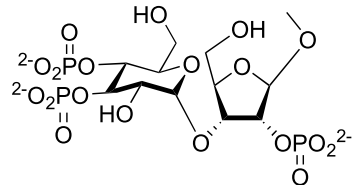

4 Ribophostin

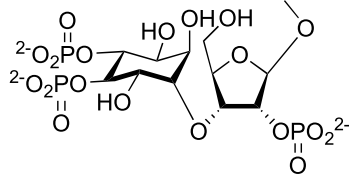

4a Inositol Ribophostin

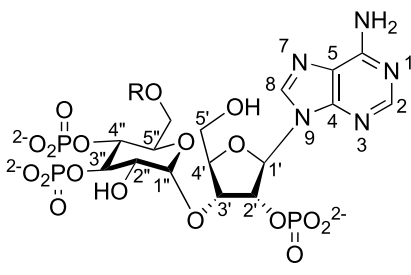

Adenophostins 2 AdA $\mathrm{R}=\mathrm{H}$

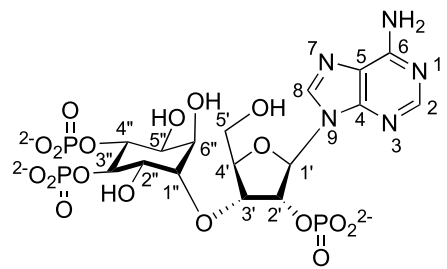

5 Inositol Adenophostin (InsAdA)

Figure 1. InsAdA (5) and other potent $\mathrm{IP}_{3} \mathrm{R}$ agonists.

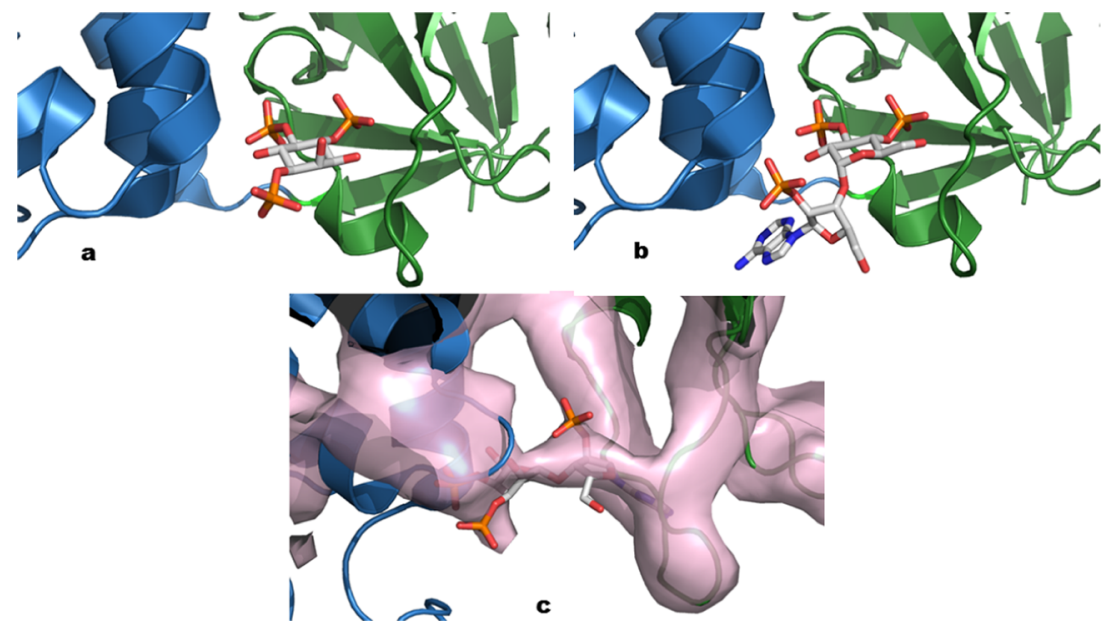

Figure 2. Binding of $\mathrm{IP}_{3}$ and $\mathrm{AdA}$ to the IBC. (a) Interaction of $\mathrm{IP}_{3}$ with the $\mathrm{IBC}$ based on the X-ray crystal structure of the IBC of IP ${ }_{3} \mathrm{R} 1$ in complex with $\mathrm{IP}_{3}$ (adapted from the Protein Data Bank, $1 \mathrm{~N} 4 \mathrm{~K}$ ). The $\alpha$ - and $\beta$-domains are shown in blue and green, respectively. (b) Model of AdA bound to the IBC of $\mathrm{IP}_{3} \mathrm{R} 1^{15}$ (adapted from the Protein Data Bank, $1 \mathrm{~N} 4 \mathrm{~K}$ ). (c) AdA bound to the IBC of IP ${ }_{3} \mathrm{R} 1$ and matching electron density map revealed by cryo-EM ${ }^{16}$ (adapted from the Protein Data Bank, 6MU1).

potency of AdA was proposed to be due to its adenosine moiety, causing a better positioning of the $2^{\prime}$-phosphate relative to the 1-phosphate of $\mathrm{IP}_{3}$, but this was not confirmed ${ }^{17}$ (vide infra). The 80 -fold loss of potency after removing the 2 phosphate from AdA to give $\mathbf{8}$ (Figure 3 ) is less than the 200fold loss of potency associated with loss of the 1-phosphate from $\mathrm{IP}_{3}{ }^{1818} \mathrm{An}$ attempt to move the 1-phosphate of $\mathrm{IP}_{3}$ further from the ring did not enhance activity. ${ }^{19}$

Removing the $\mathrm{CH}_{2} \mathrm{OH}$ group from the $\mathrm{C5}^{\prime \prime}$-position of the glucose unit has a minimal effect as indicated for xylo-AdA (Figure 3, compound 10), which is approximately twofold less potent than AdA. ${ }^{20}$ The C5' hydroxyl is also unimportant, as indicated by analogues with aromatic groups conjugated at the C5'-position (Figure 3, compound 11), both of which are equipotent with AdA. ${ }^{21}$ This allowed attachment of a large fluorescent moiety, providing both a potent fluorescent analogue of AdA and a means of measuring low concentrations of $\mathrm{IP}_{3}$. $^{222}$

An intact ribose ring is important for maintaining AdA in a conformation for binding to the IBC. Early efforts to simplify the structure of AdA led to glucopyranoside 2',3,4-tri- sphosphate (Figure 3, compound 12), ${ }^{23,24}$ a full agonist with tenfold lesser potency than $\mathrm{IP}_{3}$, indicating the likely importance of the more constrained ribose moiety to keep its phosphate group in the correct position. Acyclophostin (Figure 3, compound 13) was also designed to provide an analogue with an opened ribose ring, ${ }^{25}$ with the adenine base attached to the anomeric position of glucose via a flexible three-carbon chain. Acyclophostin has a slightly higher affinity than $\mathrm{IP}_{3}$, but its $\mathrm{Ca}^{2+}$-mobilizing activity is $\mathrm{pH}$-dependent. ${ }^{25}$ Most recently, polyphosphorylated analogues derived from both D- and L-glucose were synthesized, some of which can be viewed as truncated analogues of AdA that refine SAR understanding. ${ }^{26}$

Removal of the adenine moiety or an electron-rich aromatic ring from the $\mathrm{C1}^{\prime}$-position of AdA leads to analogues (Figure 4 , compounds 4, 14, 15) with reduced potency. ${ }^{10,17}$ Furanophostin (15) and ribophostin (4), in which the adenine is replaced with a $\mathrm{H}$ or methoxyl group, respectively, have similar potency to $\mathrm{IP}_{3}$, revealing the minimal substitution at $\mathrm{Cl}^{\prime}$ to achieve potent receptor activation. ${ }^{27,28}$ Introduction of an imidazole ring at $\mathrm{Cl}^{\prime}$ led to imidophostin (14), equipotent 


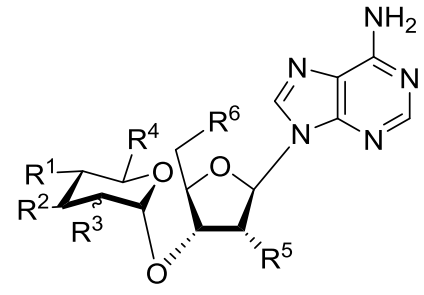

$6-11$

6 3"-Dephospho-AdA:

$\mathrm{R}^{1}=\mathrm{R}^{5}=-\mathrm{OPO}_{3}{ }^{2-}, \mathrm{R}^{3}=$ eq- $\mathrm{OH}, \mathrm{R}^{4}=\mathrm{CH}_{2} \mathrm{OH}, \mathrm{R}^{2}=\mathrm{R}^{6}=\mathrm{OH}$

7 4"-Dephospho-AdA:

$\mathrm{R}^{2}=\mathrm{R}^{5}=-\mathrm{OPO}_{3}{ }^{2-}, \mathrm{R}^{3}=$ eq-OH, $\mathrm{R}^{4}=\mathrm{CH}_{2} \mathrm{OH}, \mathrm{R}^{1}=\mathrm{R}^{6}=\mathrm{OH}$

8 2'-Dephospho-AdA:

$\mathrm{R}^{1}=\mathrm{R}^{2}=-\mathrm{OPO}_{3}{ }^{2-}, \mathrm{R}^{3}=$ eq-OH, $\mathrm{R}^{4}=\mathrm{CH}_{2} \mathrm{OH}, \mathrm{R}^{5}=\mathrm{R}^{6}=\mathrm{OH}$

9 Manno-AdA:

$\mathrm{R}^{1}=\mathrm{R}^{2}=\mathrm{R}^{5}=-\mathrm{OPO}_{3}{ }^{2-}, \mathrm{R}^{3}=a x-\mathrm{OH}, \mathrm{R}^{4}=\mathrm{CH}_{2} \mathrm{OH}, \mathrm{R}^{6}=\mathrm{OH}$

10 Xylo-AdA:

$\mathrm{R}^{1}=\mathrm{R}^{2}=\mathrm{R}^{5}=-\mathrm{OPO}_{3}{ }^{2-}, \mathrm{R}^{3}=$ eq-OH, $\mathrm{R}^{4}=\mathrm{H}, \mathrm{R}^{6}=\mathrm{OH}$

11 C5'-modified AdA:

$\mathrm{R}^{1}=\mathrm{R}^{2}=\mathrm{R}^{5}=-\mathrm{OPO}_{3}{ }^{2-}, \mathrm{R}^{3}=$ eq-OH, $\mathrm{R}^{4}=\mathrm{CH}_{2} \mathrm{OH}, \mathrm{R}^{6}=\mathrm{Ph}$ or $\mathrm{Bz}$

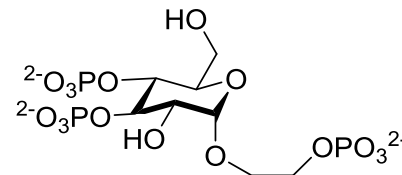

$\left.12 \operatorname{Glc}\left(2^{\prime}, 3,4\right) \mathrm{P} 3\right)$

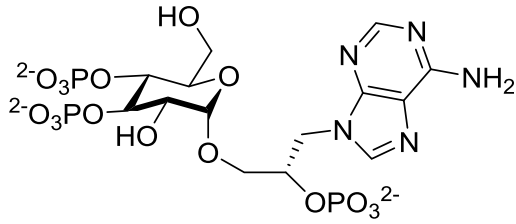

13 Acyclophostin

Figure 3. Structure of AdA analogues with varied phosphates or hydroxyls.

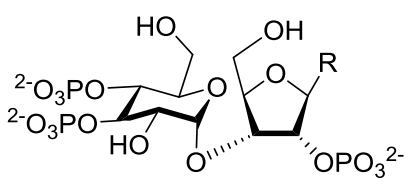

16 Purine derivatives of AdA:<smiles>[X]c1ncnc2c1ncn2C</smiles>

$X=\mathrm{H}, \mathrm{OMe}, \mathrm{NHMe}, \mathrm{NMe}_{2}$ NHcyclopentyl, NHcyclohexyl $\mathrm{NH}$ (3-noradmantyl)
4 Ribophostin:

$\mathbf{R}=\mathbf{O M e}$
15 Furanophostin:

$\mathbf{R}=\mathbf{H}$
18 Indole derivatives of AdA:

$\mathbf{R}=$<smiles>[X]c1cccc2c1ccn2C</smiles>

19 Triazole derivatives of AdA:

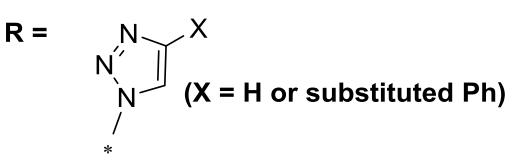

20 Triazolophostin dimers:

$\mathbf{R}=$

\section{Guanophostin A:}<smiles>[R]=Cn1cnc2c(=O)[nH]c(N)nc21</smiles>

Figure 4. Structures of AdA analogues with modified substituents at the $\mathrm{C} 1^{\prime}$-position.

with $\mathrm{IP}_{3}{ }^{2929}$ Further expansion into a simple purine base gave purinophostin 16 (Figure 4, $\mathrm{X}=\mathrm{H}$ ), nearly as potent as AdA, showing that the $N^{6}$-position may be removed. ${ }^{29}$ A bulky group is also tolerated at the $N^{6}$-position, consistent with the purine moiety being in a rather open area of the IBC. ${ }^{15}$ Similarly, guanophostin (Figure 4, compound 17) is also equipotent with $\mathrm{AdA} .{ }^{30}$ However, when the adenine is replaced with an indole, compounds (Figure 4, compound 18) show reduced binding affinity; interestingly, however, the 4 fluoroindole derivative (Figure 4, compound 18, $\mathrm{X}=\mathrm{F}$ ) is $\mathrm{IP}_{3} \mathrm{R} 1$-selective. ${ }^{31}$

More recently, a triazole ring replacement for adenine led to triazolophostins (Figure 4, compound 19), potent agonists of $\mathrm{IP}_{3} \mathrm{R}^{32}$ Triazolophostin $(19, \mathrm{X}=\mathrm{H})$ is almost as potent as AdA in releasing $\mathrm{Ca}^{2+}$ through $\mathrm{IP}_{3} \mathrm{R}$. While the imidazole analogue (Figure 4, compound $\mathbf{1 4}$ ) is only slightly more potent 


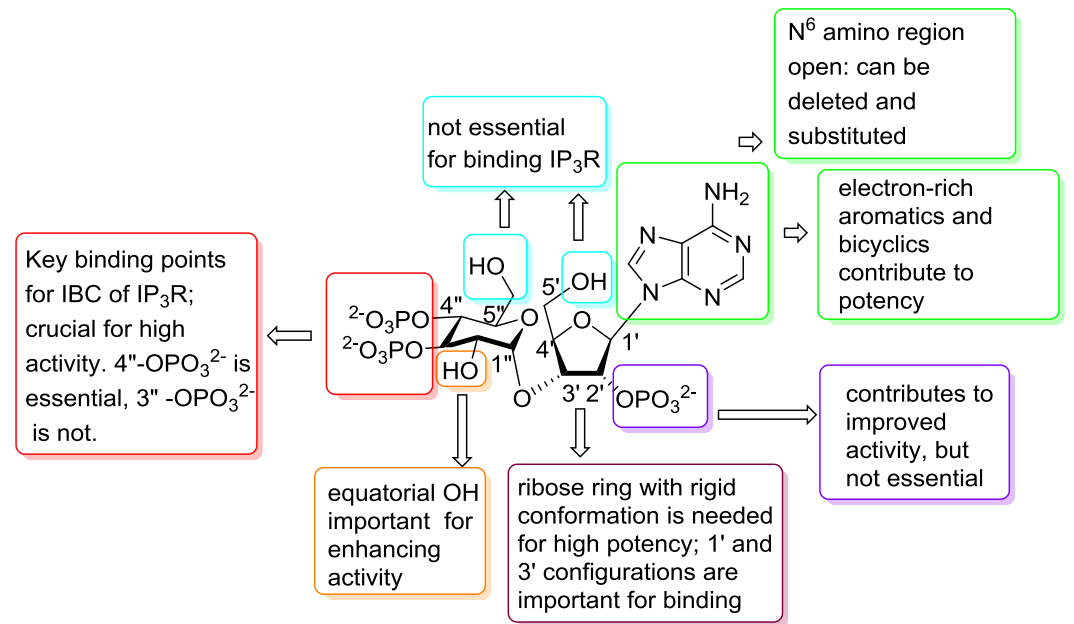

Figure 5. Structural determinants of AdA activity.

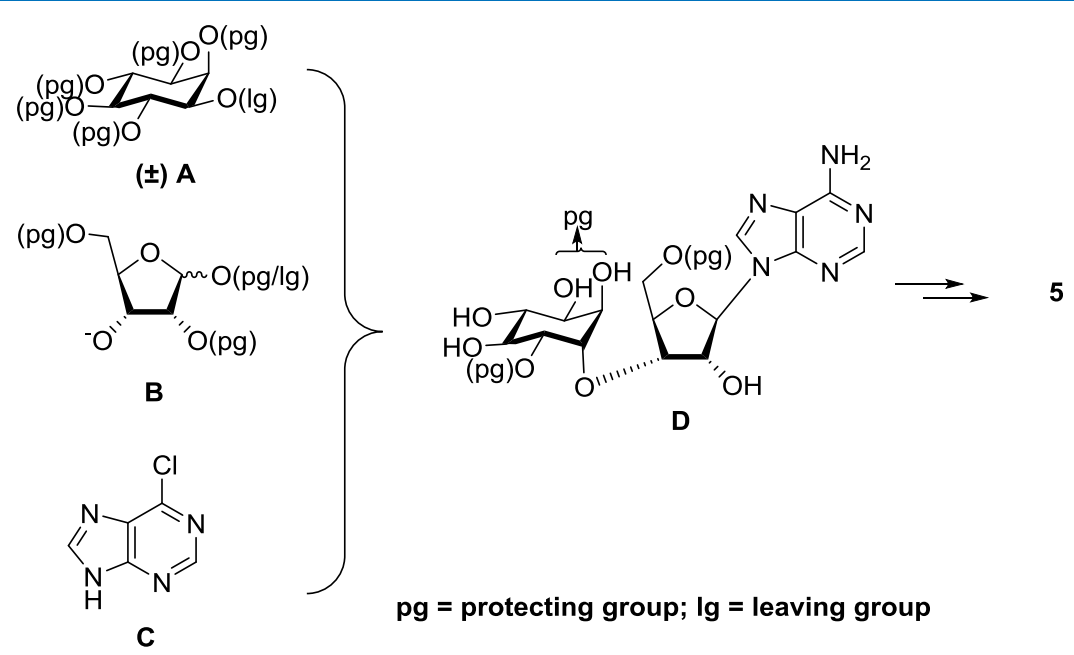

Figure 6. Convergent synthetic strategy for InsAdA (5) synthesis. (A) Protected ( \pm )-myo-inositol moiety, (B) protected D-ribose moiety, (C) 6chloropurine, and (D) protected InsAdA precusor.

than $\mathrm{IP}_{3}$, the triazole equivalent $(19, \mathrm{X}=\mathrm{H})$ is 13 times better, suggesting subtle effects on the binding. Dimer analogues (Figure 4, compound 20) are broadly equipotent to AdA. ${ }^{33}$

SAR and modeling studies suggest the potential for enhanced binding of the adenine ring with Arg504 in the IBC through a cation $-\pi$ interaction (Figure $2 b$ ). ${ }^{15,34}$ Studies with a mutated $\mathrm{IP}_{3} \mathrm{R} 1$ with Arg504 replaced by glutamine revealed reduced activity for both $\mathrm{IP}_{3}$ and AdA; however, the detrimental effect is more marked for AdA than for $\mathrm{IP}_{3}$ (353fold vs 13 -fold $\left.{ }^{17}\right)$. This concurs with the observation that Arg504 plays a far more important role in AdA binding, potentially via the cation $-\pi$ interaction. ${ }^{17,18}$ Recent analysis using single-particle cryo-EM, however, suggested a different binding mode for AdA (Figure 2c), one in which the adenine ring interacts with residues from R265 to S277 of $\beta$-TF2. ${ }^{16}$ Further investigations are needed to validate this binding mode, however, as the ligand of the model presents incorrect configurations on both glucose and ribose rings and clashes between the adenine and residues in $\beta$-TF 2 were observed (PDB 6MU1). Thus, the exact binding mode of AdA at $\mathrm{IP}_{3} \mathrm{R}$ is controversial, but our best working model is still that shown in Figure $2 b$.

Despite this extensive SAR insight, most studies have addressed iterative variations in the base, ribose, phosphate, and glucose moieties that are synthetically accessible (Figure 5). While it has long been hypothesized that in AdA the glucopyranoside moiety directly mimics inositol, direct replacement with an inositol surrogate has remained unexplored until recently when we synthesized the novel InsAdA (Figure 1) through conjugation of a protected and activated chiral myo-inositol derivative with a protected chiral ribose unit, followed by further elaboration, phosphorylation, and deblocking. ${ }^{35}$ InsAdA, with a D-chiro-inositol substituting for an $\alpha$-D-glucose moiety, was interestingly slightly more potent than AdA itself. Importantly, the extra 6" -axial hydroxyl group replacing the AdA pyranoside ring oxygen and the overall conserved high activity offer new potential for wider synthetic elaboration than just AdA itself. Moreover, although missing the adenine base, the corresponding D-chiro-inositol ribophostin counterpart (Figure 1, compound $\mathbf{4 a}$ ) is the most potent small-molecule $\mathrm{IP}_{3}$ receptor agonist without a nucleobase yet synthesized, with potency and binding affinity for $\mathrm{IP}_{3} \mathrm{R}$ approaching those of AdA. ${ }^{36}$

We now report an alternative synthetic strategy employing intrinsic D-ribose chirality and involving the separation of the diastereoisomers of a suitably protected chiro-inositol-ribonucleoside conjugate derived from a racemic myo-inositol building block. Optimal conditions for regio-monobenzylation 
Scheme 1. Synthesis of the Racemic myo-Inositol Building Block $( \pm)-(23)^{a}$

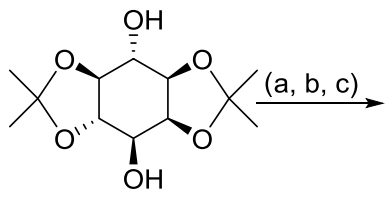

(士)-21<smiles>CC(C)(C)O[C@H]1[C@@H]2OC(C)(C)O[C@@H]2[C@H](O)[C@@H]2OC(C)(C)O[C@H]12</smiles>

$( \pm)-22$

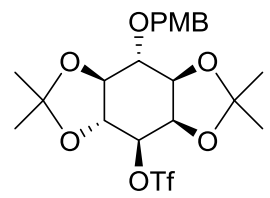

$( \pm)-23$

${ }^{a}$ Reagents and conditions: (a) tosyl imidazole (1.01 equiv), CsF (1.2 equiv), $N, N$-dimethylformamide (DMF), room temperature (rt), $18 \mathrm{~h}$; (b) $\mathrm{PMBCl}$ (1.1 equiv), $\mathrm{NaH}$ (1.2 equiv), DMF, rt, 16 h; (c) Mg (20 equiv), dichloromethane (DCM)/MeOH 1/1, reflux, 30 min, then rt, 3 h; and (d) $\mathrm{Tf}_{2} \mathrm{O}$ (1.2 equiv), pyridine, $\mathrm{DCM}, 0-25{ }^{\circ} \mathrm{C}$.
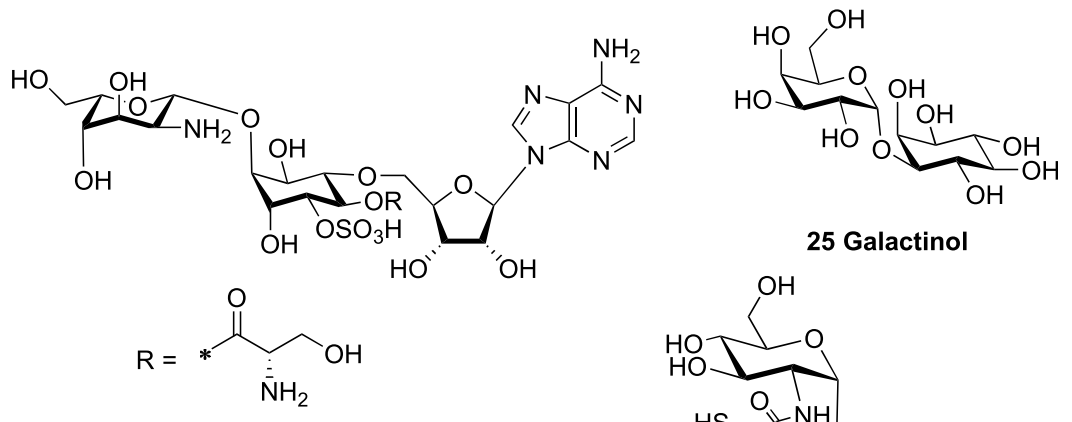

24 Adenomycin

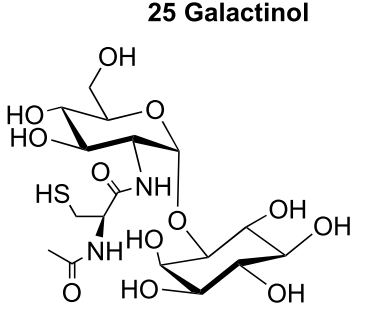

26 Mycothiol

Figure 7. Representative natural compounds containing the sugar-cyclitol moiety.

on the inositol ring of protected conjugates and for the removal of different protecting groups were also explored. InsAdA was evaluated biologically, both for its $\mathrm{IP}_{3} \mathrm{R} 1$ affinity in equilibrium competition binding assays and its ability to release $\mathrm{Ca}^{2+}$ from intracellular stores of permeabilized cells, and was directly compared with material from the earlier synthetic route.

\section{RESULTS AND DISCUSSION}

Chemistry. Our synthetic route for InsAdA involved coupling a suitably protected and activated racemic myoinositol derivative (Figure 6A) to a protected D-ribose derivative (Figure 6B) using a Williamson ether synthetic approach, followed by the introduction of a purine base (Figure 6C) and subsequent separation of the diastereoisomers of the resulting fully protected conjugates. Configurational inversion upon coupling led to the conversion of the myoinositol motif into a chiro-inositol component. Thus, the nucleoside conjugates possess both D- and L-chiro-inositol. The assignment of the absolute configuration of diastereoisomers was achieved by comparison of NMR data for material synthesized through the route using chiral precursors. ${ }^{35}$ Conditions for regioselective protection of specific hydroxyl groups on the inositol ring were explored using a stannylenemediated reaction. The fully protected conjugated isomers with benzyl protection at adjacent positions of the D-chiroinositol ring were separated successfully and transformed subsequently to InsAdA after amination, removal of paramethoxybenzyl (PMB) protection, pan-phosphorylation, and deprotection. Note, as earlier, ${ }^{35}$ that no $N^{6}$ amino protection of the adenine moiety before the phosphorylation was planned for the synthetic route.

The six secondary hydroxyl groups of myo-inositol possess similar reactivity. ${ }^{37}$ However, the reactivity of free cyclitol hydroxyls differs depending on several factors including ring conformation, hydrogen-bonding interactions with neighboring groups, and the conditions used for protection. ${ }^{4,38} \mathrm{~A}$ commonly used strategy is acid-mediated ketalization of vicinal-diol groups. ${ }^{37,39}$ Diketal $( \pm)$-1,2:4,5-di-O-isopropylidene-myo-inositol (Scheme 1, 21) can be synthesized from myo-inositol by a simple two-step process. ${ }^{40,41}$ The 1,2:4,5diketal structure forces the ring into a rigid conformation, facilitating selective individual protection of the other two free hydroxyls as a 6-O-PMB derivative and 3-O-triflate for activation. This conformational rigidity stabilizes the triflate from undergoing $\beta$-elimination under alkaline conditions. ${ }^{35}$ Less rigid combinations failed in the subsequent coupling step. $^{35}$

To tether the protected myo-inositol moiety (Figure 6A) to the ribose moiety (Figure $6 \mathrm{~B}$ ) in a second-order nucleophilic substitution $\left(\mathrm{S}_{\mathrm{N}} 2\right)$ fashion, a triflate leaving group needs to be introduced at the 3-position of 21. The $\mathrm{C} 3-\mathrm{OH}$ position of $\mathbf{2 1}$ was initially protected via a substantially selective tosylation using 1-( $p$-toluenesulfonyl)imidazole in the presence of CsF. The 3-mono-tosyl product and 3,6-di-tosyl byproduct were obtained in a respective $6: 1$ ratio, and the mixture subsequently subjected to para-methoxybenzylation, followed by detosylation using magnesium in methanol and dichloromethane $^{42}$ to give $( \pm)-22$. In the process, the 3,6-di-tosyl byproduct was converted back to $( \pm)-21$ that can be easily removed. All reactions could be achieved in an efficient one- 
Scheme 2. Synthesis of the D-Ribose Building Block (28) ${ }^{a}$

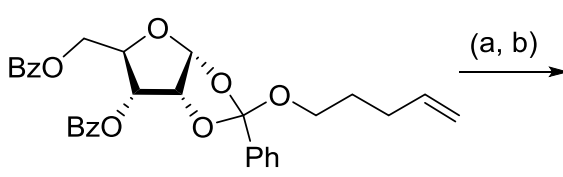

27

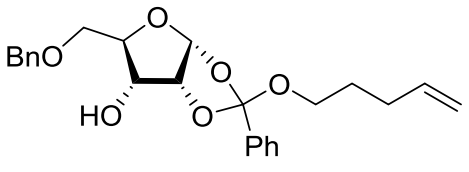

28

${ }^{a}$ Reagents and conditions: (a) $\mathrm{CH}_{3} \mathrm{ONa}$ and $\mathrm{MeOH}$ and (b) $\mathrm{BnBr}, \mathrm{Ag}_{2} \mathrm{CO}_{3}$, and toluene.

Scheme 3. Synthesis of the D- and L-chiro-Inositol Nucleoside Derivatives $(31,32)^{a}$

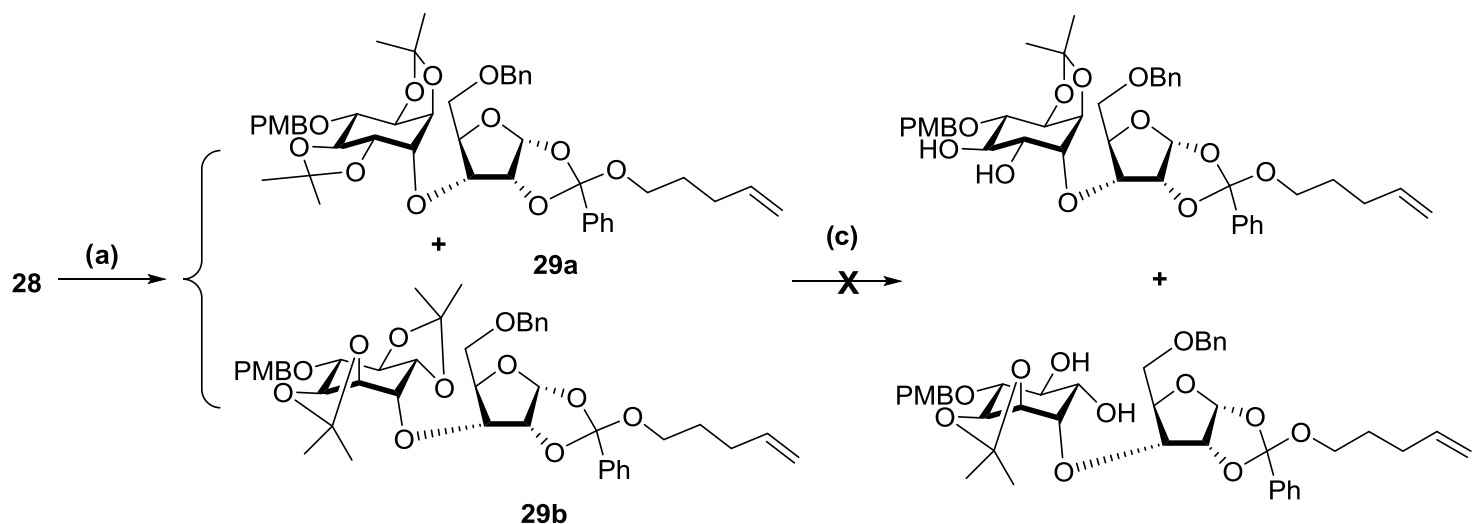

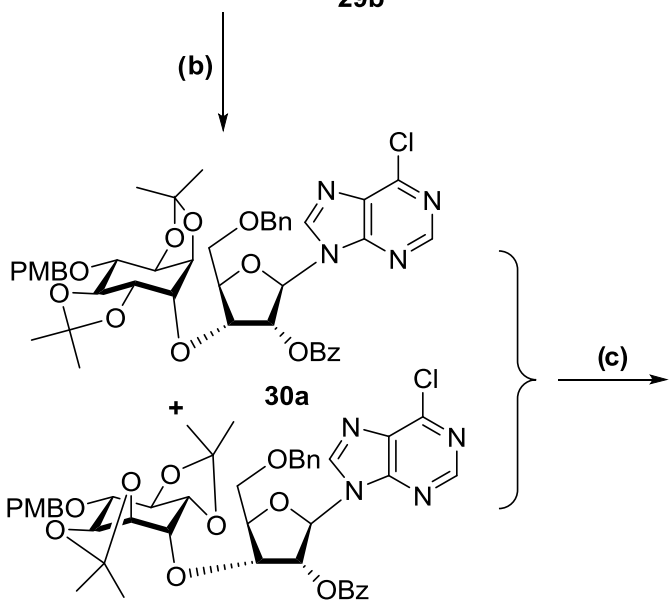

$30 \mathrm{~b}$

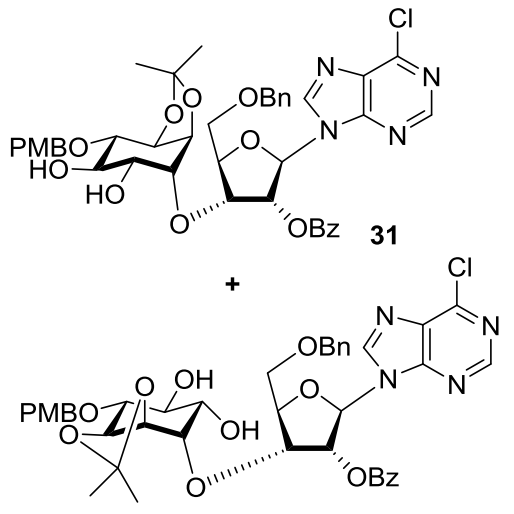

32

${ }^{a}$ Reagents and conditions: (a) ( \pm )-23, NaH, hexamethylphosphoric triamide (HMPA), tetrahydrofuran (THF), rt, $12 \mathrm{~h}$; (b) Yb(OTf) ${ }_{3}, \mathrm{NIS}$, silylated 6-chloropurine, $\mathrm{CH}_{3} \mathrm{CN}$, rt, 24 h; (c) p TSA, ethylene glycol, DCM, rt, 30 min; and column separation.

pot process, and we found that combining these three steps without separating byproducts greatly improves efficiency. The reaction of $( \pm)-22$ with triflic anhydride in the presence of pyridine in DCM generated the desired activated precursor (土)-23 (Scheme 1).

The synthesis of the diastereoisomeric conjugate between the protected DL-myo-inositol and D-ribose building blocks involved a secondary-secondary $S_{N} 2$ ether formation between the 3-oxyanion of the ribose derivative and the 3 '-O-triflate group of the myo-inositol unit. The structural feature of a chiroinositol-ribose conjugate is found in the nucleoside antibiotic molecule adenomycin (24), produced by Streptomyces griseoflavu $^{43,44}$ (Figure 7). However, in this case, the inositol is attached to the primary alcohol of the ribose. Other sugarinositol conjugates found in prokaryotic and eukaryotic cells include small molecules such as galactinol (25), ${ }^{45}$ mycothiol $(26)^{46}$ and more complex molecules such as glycosylphospha- tidylinositols (GPIs), ${ }^{47-49}$ acting as anchors for cell-surface proteins. As the inositol moiety is tethered to the anomeric position of the sugar molecule, these compounds can usually be prepared via a straightforward $O$-glycosylation reaction onto the sugar donor. ${ }^{50-52}$ The structural feature of an inositolsugar conjugate with a highly functionalized $\sec -\sec$ ether linkage as seen in InsAdA is, however, rarely reported in the literature and therefore a unique synthetic route was needed.

The D-ribose moiety (Figure 6B) needs not only to be fully protected on all hydroxyl groups except the 3-OH, but also to behave like an $\mathrm{N}$-glycosylation donor for the nucleoside synthesis. Numerous methodologies have been developed to prepare a nucleoside via an $\mathrm{N}$-glycosylation reaction. ${ }^{53}$ Among them, commonly used strategies include (a) using protected sugar halide as a donor to react with a metal salt of the nucleobase, ${ }^{54,55}$ (b) using per-acylated sugars as a donor to react with the base under fusion conditions, ${ }^{56}$ and (c) the silyl- 
Scheme 4. Optimization of the Monobenzylation of trans-Diol (33) ${ }^{a}$

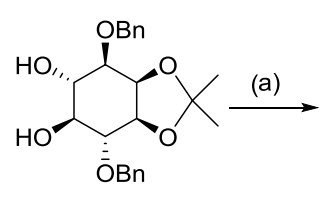

$( \pm)-33$

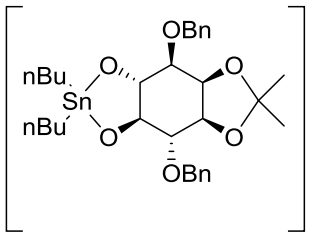

$( \pm)-34$ (b)

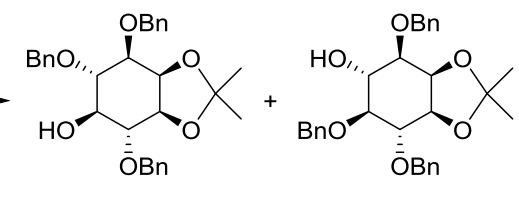

$( \pm)-35$

$( \pm)-36$

${ }^{a}$ Reagents and conditions: (a) $\mathrm{Bu}_{2} \mathrm{SnO}, \mathrm{CH}_{3} \mathrm{CN}$, and reflux and (b) $\mathrm{BnBr}$, CsF, TBAI, $3 \AA$ molecular sieves, DMF, and rt.

Table 1. Conditions for the Monobenzylation of $( \pm)-33$

\begin{tabular}{|c|c|c|c|c|c|c|}
\hline entry & $\begin{array}{c}\mathrm{Bu}_{2} \mathrm{SnO} \\
\text { (equiv) }\end{array}$ & $\begin{array}{c}\mathrm{BnBr} \\
\text { (equiv) }\end{array}$ & conditions & $\begin{array}{c}\text { yield } 35 \\
(\%)\end{array}$ & $\begin{array}{c}\text { yield } 36 \\
(\%)\end{array}$ & $\begin{array}{l}33(\%) \\
\text { recovery }\end{array}$ \\
\hline 1 & 1.1 & 2.0 & mixed solvent of $\mathrm{CH}_{3} \mathrm{OH}$ and tolulene, refluxing, phase two, TBAI, refluxing & 40 & 20 & 25 \\
\hline 2 & 1.1 & 1.5 & phase one solvent: toluene, refluxing; phase two solvent: $\mathrm{DMF}, \mathrm{CsF},-10{ }^{\circ} \mathrm{C}$ & 20 & 16 & 23 \\
\hline 3 & 1.1 & 1.5 & phase one solvent: toluene, refluxing; phase two solvent: DMF, CsF, TBAI, rt & 27 & 20 & 10 \\
\hline 4 & 2.0 & 2.0 & phase one solvent: $\mathrm{CH}_{3} \mathrm{CN}$, refluxing; phase two solvent: DMF, CsF, TBAI, rt & 35 & 18 & 25 \\
\hline 5 & 2.0 & 3.0 & $\begin{array}{l}\text { phase one solvent: } \mathrm{CH}_{3} \mathrm{CN} \text {, refluxing; phase two solvent: DMF, CsF, TBAI, } 3 \AA \\
\text { molecular sieves, } \mathrm{rt}\end{array}$ & 57 & 16 & 17 \\
\hline
\end{tabular}

Hilbert-Johnson method, modified by Vorbrüggen, that has now become the preferred methodology. ${ }^{57,58}$ This latter procedure involves a silylated heterocycle reacting with protected sugar acetate in the presence of a Lewis acid such as $\mathrm{SnCl}_{4}$ or trimethylsilyl trifluoromethanesulfonate (TMSOTf). To further improve selectivity and yield, more efficient methodologies were devised. ${ }^{59}$ Fraser-Reid developed a versatile $n$-pentenyl orthoester donor system, initially used in the synthesis of an oligosaccharide. ${ }^{60,61}$ This was later adapted into a reverse synthetic strategy for preparing ribonucleosides, which allows different structural modifications on the ribose moiety before the $N$-glycosylation occurs in very mild conditions. ${ }^{62} 3^{\prime}, 5^{\prime}$-Dibenzoyl-D-ribofuranose-1' $1^{\prime}, 2^{\prime}$-n -pentenyl orthoester (27) was prepared ${ }^{62}$ and after removing benzoyl groups, the primary alcohol was selectively protected with a benzyl group using silver carbonate ${ }^{63}$ in more than $90 \%$ yield (Scheme 2).

The $\sec -\sec$ ether formation between $\mathbf{2 8}$ and racemic $\mathbf{2 3}$ was achieved by reacting the $\mathrm{C}^{\prime}$-alkoxide of $\mathbf{2 8}$ with triflate $( \pm)-23$ under very mild conditions. The $\mathrm{C} 3 \mathrm{~S}_{\mathrm{N}} 2$ substitution of the myo-inositol moiety generated the desired conjugate of DL-chiro-inositol and D-ribose $(29 a, 29 b)$ as a pair of diastereoisomers in a 1:1 ratio in $79 \%$ yield (Scheme 3). Initial attempts to separate the diastereoisomers before $\mathrm{N}$ glycosylation were unsuccessful, as the removal of the 2,3trans-O-isopropylidene resulted in ring opening of the orthoester group (Scheme 3). The reaction of $29 a$ and $29 \mathbf{b}$ with $p$-toluenesulfonic acid ( $p$ TSA) and ethylene glycol in DCM only generated a mixture of polar byproducts. Therefore, the required 6-chloropurine base element was introduced at this stage through an $\mathrm{N}$-glycosylation reaction promoted by iodonium ion generated in situ from $\mathrm{N}$-iodosuccinimide. ${ }^{62,64}$ Reacting the silylated 6-chloropurine with $29 \mathrm{a}$ and $29 \mathrm{~b}$ in the presence of $\mathrm{N}$-iodosuccinimide, ytterbium triflate, and $3 \AA$ molecular sieve in acetonitrile at room temperature produced compounds 30a and 30b in good yields (Scheme 3). We found that adding molecular sieve powder to the system significantly improved the yield. The diastereoisomers of $30 \mathrm{a}$ and $30 \mathrm{~b}$ could not be separated with silica-based chromatography in varied solvent systems. However, selective removal of the $2^{\prime \prime}, 3$ "-trans-O-isopropylidene group generated the diols 31 and 32 that could be differentiated slightly by silica-based thin-layer chromatography (TLC). The separation of 31 and 32 was difficult using chromatography on a silica column. The optimal separation was eventually achieved by a gradient solvent system of acetone and DCM on a silica column with a loading ratio of $1: 133(\mathrm{w} / \mathrm{w}$, sample/silica). The identification of the less polar isomer 31 as possessing the D-chiro-inositol motif was performed by comparing the NMR data with those of the same compound obtained through a synthetic route with completely chiral precursors. ${ }^{35}$

The selective benzylation of the inositol $\mathrm{C}_{2}$ " $-\mathrm{OH}$ in the presence of $\mathrm{C}^{\prime \prime}-\mathrm{OH}$ needs to be conducted under mild conditions, as the purine base cannot tolerate alkylating reagents under basic conditions. ${ }^{65}$ This was illustrated by our failed attempts to benzylate the hydroxyl groups directly in the presence of $\mathrm{NaH}, \mathrm{DMF} / \mathrm{THF}$, and BnBr. With both $\mathrm{C}^{\prime \prime}$ and the C3" hydroxyls being equatorial, they are positioned in a very similar environment in terms of stereochemistry and hydrogen-bonding capacity. ${ }^{66}$ Several conditions for the regioselective alkylation of sugar molecules have been reported using an organic metal reagent as an activator, including an organotin, ${ }^{67}$ nickel complex, ${ }^{68}$ silver salt, ${ }^{63}$ and, more recently, an iron complex. ${ }^{69}$ Organotin compounds such as dibutyltin oxide and tributyltin oxide are still widely used for selective manipulation of carbohydrate molecules, ${ }^{70,71}$ despite their potential toxicity. Regioselective alkylations were achieved through the preactivation of the two adjacent hydroxyl groups by forming a cyclic dioxolane-like intermediate with the organotin reagent. It was noted, however, that tin-mediated benzylation reactions on trans-diols are less selective as those on cis-diols. ${ }^{72}$

To establish suitable conditions for the monobenzylation on the desired 31, we used the myo-inositol derivative racemic 33 as a model for optimizing the tin-mediated reaction (Scheme 4). Benzylation of 33 had been previously performed under either strongly basic conditions ${ }^{73}$ or via tin-mediated one-pot reaction conditions. ${ }^{74}$ We used a two-phase reaction condition, i.e., isolation of the stannylene-ketal intermediate 34 before adding $\mathrm{BnBr}$, to avoid possible benzylation on the purine moiety. Initially, the reaction was performed in a mixed solvent of toluene and methanol for both phases (Table 1, entry 1). However, no product was observed when the second phase was conducted at room temperature after 3 days. Even though 
Scheme 5. Monobenzylation of the Conjugate Containing the L-chiro-Inositol Motif (32) ${ }^{a}$

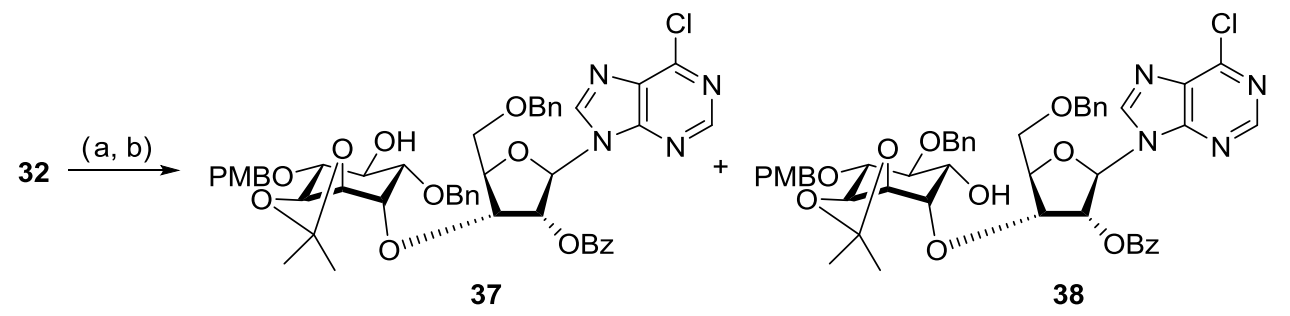

${ }^{a}$ Reagents and conditions: (a) $\mathrm{Bu}_{2} \mathrm{SnO}, \mathrm{CH}_{3} \mathrm{CN}$, and reflux and (b) $\mathrm{BnBr}$, CsF, TBAI, $3 \AA$ molecular sieves, DMF, and rt.

Scheme 6. Synthesis of InsAdA (5) ${ }^{a}$
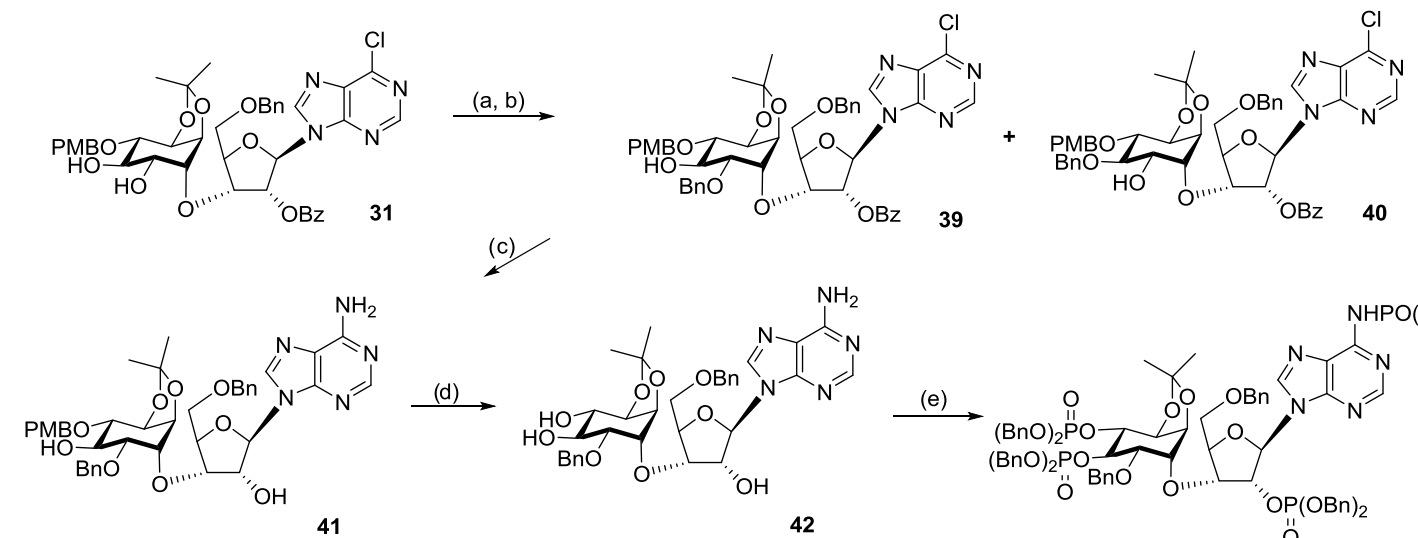

(c)
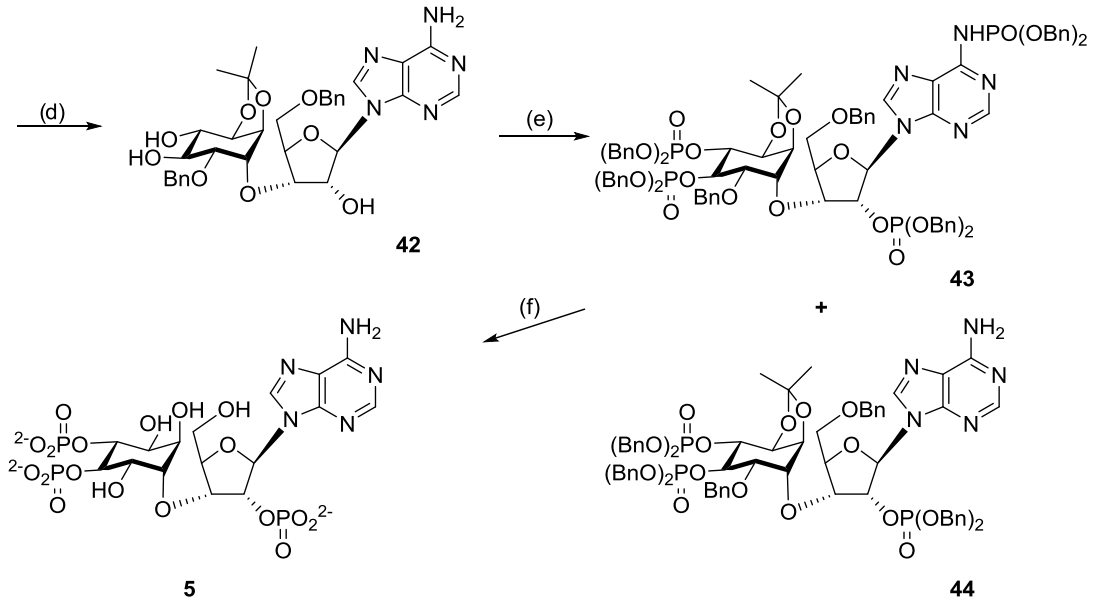

${ }^{a}$ Reagents and conditions: (a) $\mathrm{Bu}_{2} \mathrm{SnO}, \mathrm{CH}_{3} \mathrm{CN}$, reflux, $18 \mathrm{~h}$; (b) BnBr, CsF, TBAI, $3 \AA$ molecular sieves, DMF, rt, 16 h; (c) $\mathrm{NH}_{3}, \mathrm{C}_{2} \mathrm{H}_{5} \mathrm{OH}, 78$ ${ }^{\circ} \mathrm{C}, 20 \mathrm{~h}$; (d) $10 \%$ trifluoroacetic acid (TFA), DCM, rt, $4 \mathrm{~min}$; (e) (BnO) ${ }_{2} \mathrm{PN}(i-\mathrm{Pr})_{2}$, imidazolium triflate, DCM/CD $\mathrm{Cl}_{2}, \mathrm{rt}, 1 \mathrm{~h}$, then tert-BuOOH $(70 \%),-78{ }^{\circ} \mathrm{C}$ to rt in $30 \mathrm{~min}$; and (f) $20 \% \mathrm{Pd}(\mathrm{OH})_{2} / \mathrm{C}$, cyclohexene, $\mathrm{MeOH} / \mathrm{H}_{2} \mathrm{O}$, reflux, $18 \mathrm{~h}$.

products 35 and 36 could be obtained in $40 \%$ and $20 \%$ yields, respectively, after refluxing the reaction mixture for $32 \mathrm{~h}$, this condition is not suitable for the target molecule $\mathbf{3 1}$ due to potential interference with the purine ring. We changed the solvent for the second phase to DMF and used CsF (Table 1, entry 2) or CsF/TBAI (Table 1, entry 3) as catalysts. Compound 35 was obtained in $20 \%$ and $27 \%$ yields; however, the other regioisomer 36 was also produced in 16-20\% yield, indicating low selectivity. Increasing both dibutyltin oxide and $\mathrm{BnBr}$ to 2 equiv and changing the solvent for the first phase to acetonitrile improved the selectivity slightly to $2: 1$ (Table 1, entry 4). The reaction was then conducted with $3 \AA$ molecular sieves added to the system on the second phase and, with benzyl bromide increased to 3 equiv, compound 35 was obtained in $57 \%$ yield with a preference ratio of 3.5:1 (Table 1, entry 5).

The benzylation conditions from Table 1, entry 5 were translated to the "undesired" diastereoisomer (32) containing the L-chiro-inositol motif as a model (Scheme 5). The monobenzylated products 37 and $\mathbf{3 8}$ were obtained in 58\% yield. ${ }^{1} \mathrm{H}$ NMR spectroscopy indicated that the two regioisomers were present in a 3:1 ratio. These two compounds were inseparable by a silica-based chromatography system. The same benzylation condition was then used on the "desired" D-chiro-inositol derivative 31. However, the benzylation was unfortunately much slower and less selective. Compounds 39 and $\mathbf{4 0}$ were obtained in $26 \%$ and $31 \%$ yields, respectively, with $27 \%$ of the starting material 31 recovered (Scheme 6). It was hypothesized that the behavioral difference toward the benzylation process between the two diastereoisomers 31 and 32 was due to stereo effects positioning the two adjacent hydroxyl groups in $\mathbf{3 1}$ in a hindered location. An AMMP force field minimization and conformational search were conducted for 31 with the VEGA ZZ program (version 3.1.1). ${ }^{75}$ With torsions set for $\mathrm{C}-\mathrm{O}-\mathrm{C}$ linker between the ribose and inositol parts and $O$-benzoyl group on the ribose ring, the lowest energy conformers with ribose in both $2^{\prime}$-Cendo and $3^{\prime}$-C-endo conformations indicated that the two hydroxyl groups were positioned between the inositol ring and the benzoyl ring, whereas for the "undesired" diastereoisomer 32 , the two adjacent hydroxyl groups were positioned in a more exposed area.

Removal of the para-methoxybenzyl (PMB) group can be achieved by an oxidative process using 2,3-dichloro-5,6- 
Scheme 7. PMB Removal Model Reaction ${ }^{a}$

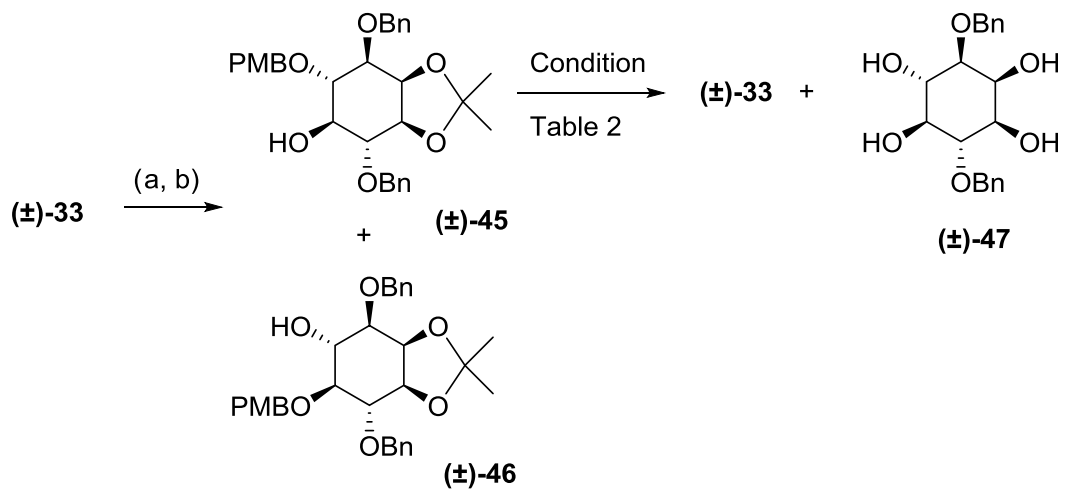

$( \pm)-46$

${ }^{a}$ Reagents and conditions: (a) $\mathrm{Bu}_{2} \mathrm{SnO}, \mathrm{CH}_{3} \mathrm{CN}$, and reflux and (b) $\mathrm{PMBCl}, \mathrm{CsF}$, TBAI, $3 \AA$ molecular sieves, DMF, and rt.

dicyanobenzoquinone (DDQ $)^{76}$ or ceric ammonium nitrate (CAN). ${ }^{77}$ The conditions of $10 \%$ TFA in DCM have been successfully employed to remove $\mathrm{PMB}$ groups from sugar molecules without affecting the glycosidic linkage. ${ }^{78}$ Because of the presence of the sensitive 2,3-O-isopropylidene group, we initially avoided acidic conditions when deprotecting the model molecule $\mathbf{4 5}^{74}$ (Scheme 7 ). However, the oxidative process using CAN only generated the target compound 33 in low yield, along with the fully hydrolyzed byproduct 47 (Table 2 , entry 1). The same reaction performed using a phosphate

Table 2. Conditions for PMB Removal from ( \pm )-45

\begin{tabular}{|c|c|c|c|}
\hline entry & conditions & $\begin{array}{c}(33) \\
\text { yield } \\
(\%)\end{array}$ & $\begin{array}{c}(47) \\
\text { yield } \\
(\%)\end{array}$ \\
\hline 1 & $\mathrm{CAN}, \mathrm{CH}_{3} \mathrm{CN} / \mathrm{H}_{2} \mathrm{O}$, rt. $45 \mathrm{~min}$ & 19 & 13 \\
\hline 2 & $\begin{array}{l}\mathrm{CAN}, \mathrm{CH}_{3} \mathrm{CN} / \mathrm{H}_{2} \mathrm{O}, \mathrm{Na}_{2} \mathrm{HPO}_{4}-\mathrm{NaH}_{2} \mathrm{PO}_{4} \text {, } \\
\text { buffer, pH 7.4, rt, } 40 \mathrm{~min}, 0{ }^{\circ} \mathrm{C}\end{array}$ & 25 & \\
\hline 3 & $\begin{array}{l}\mathrm{DDQ}, \mathrm{DCM} / \mathrm{H}_{2} \mathrm{O}, \mathrm{Na}_{2} \mathrm{HPO}_{4}-\mathrm{NaH}_{2} \mathrm{PO}_{4} \\
\text { buffer, } \mathrm{pH} 7.4, \mathrm{rt}, 1.5 \mathrm{~h}, 0{ }^{\circ} \mathrm{C}\end{array}$ & 55 & \\
\hline 4 & $\begin{array}{l}\text { 10\% TFA/DCM dried over } 3 \AA \text { molecular } \\
\text { sieves, rt, } 3 \mathrm{~min}\end{array}$ & 80 & \\
\hline 5 & $\begin{array}{l}10 \% \text { TFA/DCM dried over } 3 \AA \text { molecular } \\
\text { sieves, } 0{ }^{\circ} \mathrm{C}, 10 \mathrm{~min}\end{array}$ & 55 & 25 \\
\hline
\end{tabular}

buffer system only improved the yield slightly (Table 2, entry 2). Using DDQ instead of CAN in the buffer system gave a significantly improved yield of 55\% without the detection of byproduct 47 (Table 2, entry 3). However, the messy procedure of working up the DDQ reaction prompted us to try the TFA deprotection method ${ }^{78}$ on racemic 45 . Surprisingly, the PMB ether of $\mathbf{4 5}$ was cleaved in as short a time as 3-4 min and gave an $80 \%$ yield of the product 33 (Table 2, entry 4). Longer reaction times even at lower temperatures generated more byproduct 47 (Table 2, entry 5). Therefore, using the same conditions in Table 2, entry 4, compound 41 was converted to the desired precursor 42 in $63 \%$ yield.

The protected phosphate groups at the $\mathrm{C} 2{ }^{\prime}$-position of the ribose component and the $3^{\prime \prime}, 4^{\prime \prime}$-positions of the inositol component could be introduced via a phosphitylation reaction, followed by oxidation of the resulting $\mathrm{P}$ (III) intermediate to the corresponding $\mathrm{P}(\mathrm{V})$ triphosphate. Phosphoramidites are among the most widely used phosphitylation reagents with the advantage of being highly reactive, easily accessible, and, importantly, being able to react with hydroxyl groups under very mild conditions. ${ }^{79}$ Phosphoramidite reagents are usually activated by weak acids such as $1 H$-tetrazole ${ }^{80} 5$-( $p$-nitrophenyl)- $1 H$-tetrazole; ${ }^{81}$ 4,5-dicyanoimidazol; ${ }^{82}$ benzimidazolium triflate; ${ }^{83}$ or imidazolium, anilinium, and pyridinium salts. ${ }^{84}$ Some activators such as pyridinium hydrochloride with aniline $^{85}$ or imidazolium triflate ${ }^{86}$ could selectively promote $O$ phosphorylation over $\mathrm{N}$-phosphorylation, therefore avoiding the necessity of protecting $\mathrm{NH}_{2}$ of nucleotide base.

Part of our strategy was not to protect the amino group of adenine. However, when $\mathbf{4 2}$ was reacted with 5.3 molar equiv of dibenzyl $N, N$-diisopropylphosphoramidite, preactivated with imidazole triflate, and the product subsequently oxidized with tert-butyl hydroperoxide, no significant selectivity between $\mathrm{OH}$ groups and the adenine $\mathrm{NH}_{2}$ was observed; a mixture of tetrakisphosphate 43 and the desired trisphosphate 44 was obtained in a respective $4: 3$ ratio (Scheme 6). $N^{6}$ phosphoramidate was distinguished easily from the other phosphotriesters by its ${ }^{1} \mathrm{H}$ NMR resonance at $8.67 \mathrm{ppm}$ for $\mathrm{NH}$ and a ${ }^{31} \mathrm{P}$ NMR broad peak at $0.90 \mathrm{ppm}$. Nonselectivity was most likely due to an excess amount of phosphoramidite, which was used to ensure the complete hydroxyl phosphorylation.

$N$-Phosphoramidates can be hydrolyzed using strongly acidic, ${ }^{87-90}$ strongly basic, or metallic reagents. ${ }^{91}$ Hydrogenation of $\mathrm{N}$-phosphate benzyl ester generated partially deprotected phosphoramidate that could be further converted to the fully deblocked free amino compound under controlled mild acidic conditions. ${ }^{92}$ Our final deprotection step was performed using a catalytic hydrogen transfer reaction with $\mathrm{Pd}(\mathrm{OH})_{2}$ as a catalyst and cyclohexene as a hydrogen source. After refluxing the mixed tris- $O$-phosphate-mono- $N$-phosphoramidate benzyl esters 43 in a mixture of methanol-watercyclohexene over $\mathrm{Pd}(\mathrm{OH})_{2}$ on charcoal for $18 \mathrm{~h}$, all protecting groups were removed, leading to the final target compound 5 in its free acid form. The concomitant removal of the $\mathrm{N}$ phosphate and $\mathrm{O}$-isopropylidene groups, attributed to the intrinsic acidity of the free phosphate groups, was observed in our earlier work. ${ }^{35}$ The strategy of removing four different types of protecting groups efficiently in a single step is particularly useful in solution-phase nucleotide synthesis to avoid cumbersome extra $\mathrm{N}$-protection methods. Furthermore, the strategy is more suitable when the availability of only small amounts of material might preclude the easy use of phosphoramidite activators, e.g., imidazolium triflate for selective $O$ - vs $N$-phosphitylation since this requires very careful titration of reagents and rigorous exclusion of water. ${ }^{93}$ Purification using semipreparative reverse-phase high-perform- 

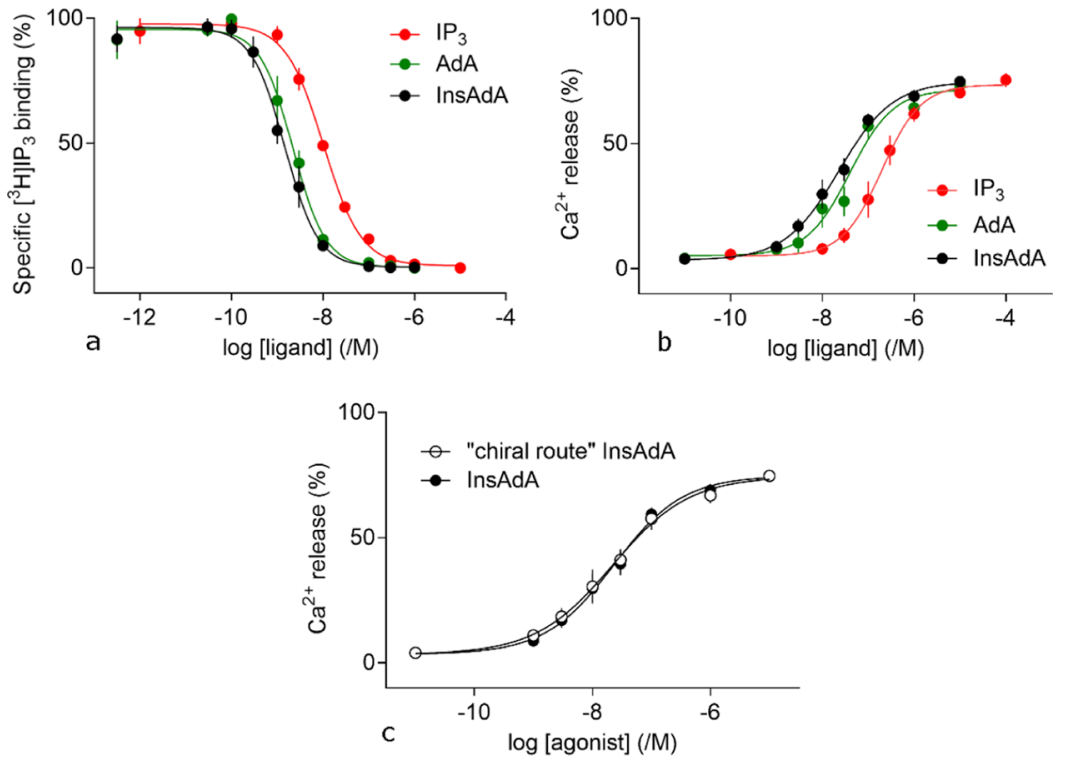

Figure 8. (a) Equilibrium competition binding to cerebellar membranes using $\left[{ }^{3} \mathrm{H}\right]-\mathrm{IP}_{3}(1.5 \mathrm{nM})$ and the indicated concentrations of related ligands. Results are means \pm SEM from three independent experiments. Summary results in Table 3. (b) Concentration-dependent effects of $\mathrm{IP}_{3}$, AdA, and InsAdA on $\mathrm{Ca}^{2+}$ release from intracellular stores. Results (\% of $\mathrm{Ca}^{2+}$ content, means $\left.\pm \mathrm{SEM}, n=6\right)$ show $\mathrm{Ca}^{2+}$ release from the intracellular stores of permeabilized HEK-IP ${ }_{3} \mathrm{R} 1$ cells evoked by the indicated concentrations of ligands. Summary of the results presented in Table 4. (c) Concentration-dependent effects of InsAdA obtained via two different synthetic routes on $\mathrm{Ca}^{2+}$ release from intracellular stores. Results (\%, means \pm SEM, $n=6$ ) show $\mathrm{Ca}^{2+}$ release from the intracellular stores of permeabilized HEK-IP ${ }_{3} \mathrm{R} 1$ cells evoked by the indicated concentrations of InsAdA and "chiral route" InsAdA. There were no significant differences between the ligands in the values for $\mathrm{Ca}^{2+}$ release $(\%)$ or $\mathrm{pEC}_{50}(P<0.05)$. $\mathrm{pEC}_{50}=7.65 \pm 0.14$ and $7.67 \pm 0.14$ for InsAdA and "chiral route" InsAdA, respectively. $\mathrm{Ca}^{2+}$ release $(\%)=74 \pm 2$ and $72 \pm 3$ for InsAdA and "chiral route" InsAdA, respectively. (A) Data for $\mathrm{IP}_{3}$ and AdA $\left(\mathrm{Ca}^{2+}\right.$ assays) are adapted in part with permission from ref 35 . Copyright 2020 Royal Society of Chemistry. (B) Data for $\mathrm{IP}_{3}$ and AdA (binding assays) are adapted in part from ref 36. Copyright 2020 American Chemical Society; further permissions related to the material excerpted should be directed to the ACS. (C) Data for InsAda "chiral route" are adapted in part with permission from ref 35. Copyright 2020 Royal Society of Chemistry.

ance liquid chromatography (HPLC) with $0.1 \mathrm{M}$ tetraethylammonium bromide (TEAB) $-\mathrm{MeCN}$ as an eluant gave the target InsAdA as its triethylammonium salt as a colorless glass after evaporation of buffer in vacuo.

In comparison with our earlier synthetic method using a chiral inositol building block as a precursor, ${ }^{35}$ the alternative approach reported here achieved the fully chiral target molecule using just the intrinsic protected D-ribose unit chirality to avoid resolution at an early stage, thus saving several steps. The present synthetic route should therefore offer a somewhat more economical and practical approach than that reported earlier, ${ }^{35}$ especially to the now anticipated further analogues of this highly potent ligand and those exploiting substitutions on the $6^{\prime \prime}$-axial hydroxyl group that replaces the pyranoside ring oxygen of AdA. Equally, this broad synthetic approach may also be applicable to such analogues of D-chiroinositol ribophostin (Figure 1, compound 4a), ${ }^{36}$ a related and simpler ligand that showed unexpectedly potent Ins $\mathrm{P}_{3} \mathrm{R}$ activity in comparison to its disaccharide counterpart ribophostin and worthy of further development.

Biology. We assessed the ability of InsAdA to bind with $\mathrm{IP}_{3} \mathrm{R}$ and stimulate $\mathrm{Ca}^{2+}$ release. In equilibrium competition binding assays using $\left[{ }^{3} \mathrm{H}\right]-\mathrm{IP}_{3}$, InsAdA bound to the fulllength $\mathrm{IP}_{3} \mathrm{R} 1$ of cerebellar membranes with greater affinity than $\mathrm{IP}_{3}$, and its affinity was slightly, but not significantly, higher than that of AdA (Figure 8a and Table 3). The shared features of InsAdA and AdA provide likely explanations for the high affinity of InsAdA. The cyclitol ring of InsAdA most likely adopts a conformation that locates the critical $3 ", 4^{\prime \prime}$ bisphosphates in the same area as that of the $3^{\prime \prime}, 4^{\prime \prime}$ -
Table 3. Effects of Ligands on $\left[{ }^{3} \mathrm{H}\right]-\mathrm{IP}_{3}$ Binding to Cerebellar Membranes ${ }^{a}$

\begin{tabular}{lccc}
\multicolumn{1}{c}{ ligand } & $\mathrm{p} K_{\mathrm{d}}$ & $K_{\mathrm{d}}(\mathrm{nM})$ & $h$ \\
$\mathrm{IP}_{3}(\mathbf{1})$ & $8.06 \pm 0.03$ & 8.71 & $1.1 \pm 0.2$ \\
$\mathrm{AdA}(\mathbf{2})$ & $8.86 \pm 0.14$ & 1.38 & $1.2 \pm 0.2$ \\
InsAdA (5) & $8.90 \pm 0.11$ & 1.26 & $1.2 \pm 0.1$
\end{tabular}

${ }^{a}$ Results are means \pm standard error of the mean $($ SEM $)\left(\mathrm{p} K_{\mathrm{d}}\right.$ and $\left.h\right)$ and means $\left(K_{\mathrm{d}}\right)$ from three independent experiments. $K_{\mathrm{d}}$, equilibrium dissociation constant; $\mathrm{p} K_{\mathrm{d}},-\log K_{\mathrm{d}} ; h$, Hill coefficient. There were no significant differences between the ligands in the values for $h$. The $\mathrm{p} K_{\mathrm{d}}$ values were significantly different $(P<0.05)$, for $\mathrm{IP}_{3}$ vs $\mathrm{AdA}$ and $\mathrm{IP}_{3}$ vs InsAdA. Values for $\mathrm{IP}_{3}$ and AdA (as all ligands were run in parallel in binding assays) are from ref 36.

bisphosphates of $\mathrm{AdA}$, and the $\mathrm{C} 2^{\prime \prime}-\mathrm{OH}$ of inositol sits in the area occupied by the 2 "-OH of AdA. The rigidity of the ribose unit plays a key role in keeping the geometrical relationship of the cyclitol and adenine rings, which is critical for the electron-rich adenine ring to interact with positively charged residues in the IBC and presumably Arg504. The exposed cis-diols in InsAdA are unlikely to have a substantial impact on the binding affinity; however, they may function as versatile handles to attach other groups for further SAR study and antagonist design.

In assays of $\mathrm{Ca}^{2+}$ release from the intracellular stores of permeabilized HEK cells expressing only $\mathrm{IP}_{3} \mathrm{R} 1$ ( $\mathrm{HEK}-\mathrm{IP}_{3} \mathrm{R} 1$ cells), maximally effective concentrations of $\mathrm{IP}_{3}$, AdA, or InsAdA released the same fraction $(\sim 70 \%)$ of the intracellular $\mathrm{Ca}^{2+}$ stores. However, InsAdA was more potent than either AdA or $\mathrm{IP}_{3}$ (Figure $8 \mathrm{~b}$ and Table 4 ). The potency of InsAdA 
Table 4. Effects of Ligands on $\mathrm{Ca}^{2+}$ Release from the Intracellular Stores of Permeabilized HEK-IP ${ }_{3}$ R1 Cells ${ }^{a}$

\begin{tabular}{lcccc}
\multicolumn{1}{c}{ ligand } & $\mathrm{pEC}_{50}$ & $\mathrm{EC}_{50}(\mathrm{nM})$ & $\mathrm{Ca}^{2+}$ release (\%) & $h$ \\
$\mathrm{IP}_{3}(\mathbf{1})$ & $6.73 \pm 0.13$ & 186 & $73 \pm 2$ & $1.2 \pm 0.1$ \\
$\mathrm{AdA} \mathrm{(2)}$ & $7.45 \pm 0.16$ & 35 & $71 \pm 3$ & $1.5 \pm 0.4$ \\
InsAdA (5) & $7.65 \pm 0.14$ & 22 & $74 \pm 2$ & $1.0 \pm 0.2$
\end{tabular}

${ }^{a}$ Results are means \pm SEM $\left(\mathrm{pEC}_{50}, \mathrm{Ca}^{2+}\right.$ release $(\%)$, and $\left.h\right)$ and means $\left(\mathrm{EC}_{50}\right)$ from six independent experiments each performed in duplicate. $\mathrm{EC}_{50}$, half-maximally effective concentration. There were no significant differences between the ligands in the values for $\mathrm{Ca}^{2+}$ release $(\%)$ or $h$. The $\mathrm{pEC}_{50}$ values were significantly different $(P<$ 0.05 ) for $\mathrm{IP}_{3}$ vs $\mathrm{AdA}, \mathrm{IP}_{3}$ vs InsAdA, and AdA vs InsAdA. Values for $\mathrm{IP}_{3}$ and AdA are taken from ref 35.

was the same as that determined for compounds obtained via a totally chiral synthetic route ("chiral route" InsAdA, Figure 8c). ${ }^{35} \mathrm{IP}_{3}$ and AdA are full agonists; ${ }^{94}$ we therefore used the ratio of the concentrations of ligand required to evoke halfmaximal $\mathrm{Ca}^{2+}$ release $\left(\mathrm{EC}_{50}\right)$ and to occupy $50 \%$ of $\mathrm{IP}_{3} \mathrm{Rs}$ (equilibrium dissociation constant, $K_{\mathrm{d}}$ ), the $\mathrm{EC}_{50} / K_{\mathrm{d}}$ ratio, as an indication of agonist efficacy, which is the ability of the ligand to activate the $\mathrm{IP}_{3} \mathrm{R}$ once it has bound to it. The $\mathrm{EC}_{50} /$ $K_{\mathrm{d}}$ ratios were similar for all three ligands (Table 5), suggesting that InsAdA is a full agonist of $\mathrm{IP}_{3} \mathrm{R}$.

Table 5. $\mathrm{EC}_{50} / K_{\mathrm{d}}$ Ratios of $\mathrm{IP}_{3}$, AdA, and InsAdA ${ }^{a}$

\begin{tabular}{lc}
\multicolumn{1}{c}{ ligand } & $\mathrm{EC}_{50} / K_{\mathrm{d}}(95 \% \mathrm{CI})$ \\
$\mathrm{IP}_{3}(\mathbf{1})$ & $22(8-59)$ \\
$\mathrm{AdA}(\mathbf{2})$ & $25(6-100)$ \\
InsAdA (5) & $18(6-58)$
\end{tabular}

${ }^{a} \mathrm{EC}_{50} / K_{\mathrm{d}}$ ratio is used as an indication of efficacy. There were no significant differences between the ligands in the values for the $\mathrm{EC}_{50}$ / $K_{\mathrm{d}}$ ratios (mean with $95 \%$ confidence interval, $n=6$ ), suggesting that like $\mathrm{IP}_{3}$ and AdA, InsAdA is a full agonist of the $\mathrm{IP}_{3} \mathrm{R}$.

Thus, we have shown that a convergent synthetic route can achieve the target InsAdA, fully active in two biological assays, using the intrinsic chirality of a D-ribose building block and without an early resolution step. InsAdA prepared by this route is biologically equipotent with that from the synthetic route using only chiral precursors. ${ }^{35}$ Now that the high potency of InsAdA has been reaffirmed, this ligand also provides importantly and, unlike its parent AdA, an axial cyclitol hydroxyl group for potential further synthetic elaboration. As will be noted from the position of the pyranoside oxygen of AdA in the binding model in Figure 2a, its replacement with an axial hydroxyl, ${ }^{35}$ if mirrored by InsAdA binding, should offer through suitably substituted derivatives, the potential for direct targeting of the IBC clam cleft that may be useful in the future antagonist design.

It is naturally tempting to speculate why InsAdA is slightly more potent than AdA and how this might relate to the simple replacement of a glucose with chiro-inositol. This is clearly the first example of such an analogue, and even though this might be viewed as a relatively conservative modification, the consequences at an SAR level are likely to be multifactorial and the SAR profiles rehearsed above may not be definitive enough to rationalize its activity. This may best be tackled when further such InsAdA analogues with modifications to the chiro-inositol ring are synthesized and evaluated biologically. Activity ideally needs to be benchmarked to more members of a closely related structural series and perhaps also in concert with studies on $\mathrm{IP}_{3} \mathrm{R}$-binding site mutants. For the present, however, we might reasonably assume that InsAdA could bind in a similar fashion to AdA, with its vicinal bisphosphates engaging the same receptor elements as for AdA and $\mathrm{IP}_{3}$ and its adenine still interacting specifically with Arg504 as for AdA, and according to our working model (Figure 2b). Previously rehearsed possibilities for mimicry of the $1^{\prime}$-phosphate of $\mathrm{IP}_{3}$ by the $2^{\prime \prime}$-phosphate of AdA involving Arg568 14,17 of the $\alpha$ domain may also be valid. Conformational flexibility, however, is likely to be impacted through the broad structural change initiated in InsAdA. We should also note that InsAdA represents two pharmacophoric components conjoined through an ether linkage and not via the disaccharide linkage of AdA. Overall conformation might be influenced by exoanomeric and other steric effects different from AdA and conformational populations presented to the $\mathrm{IP}_{3} \mathrm{R}$ could differ between the two ligands. For the present, it is encouraging to note that the high potency of AdA has been closely maintained in the new analogue, which importantly offers slightly more synthetic diversity for development. Thus, the potential for using InsAdA to design further ligands of interest is recognized, although the obvious difficulty and length of the synthetic procedures to access InsAdA analogues may well be a limiting factor in progressing this series.

\section{CONCLUSIONS}

We have developed an alternative synthetic strategy for InsAdA (5), a molecule that combines many structural features of $\mathrm{IP}_{3}$, the native ligand of $\mathrm{IP}_{3} \mathrm{R}$, with $\mathrm{AdA}$, the most potent agonist of $\mathrm{IP}_{3} \mathrm{R}$. The core structural template with a D-chiro-inositol tethered to a ribonucleoside via a $\sec -\sec$ ether linkage is rarely found in the literature. The chiro-inositol-ribonucleoside diastereoisomers $(31,32)$ from coupling of a suitably protected and activated racemic myo-inositol building block to a suitably protected ribose derivative were successfully separated after purine glycosidation and partial deprotection; the desired D-chiro-inositol-ribonucleoside conjugate (31), after configurational assignment, was subsequently converted to the target compound through monobenzylation of the vicinal inositol trans-diol, amination of chloropurine, PMB removal, pan-phosphorylation, and finally full deblocking of all protection. InsAdA was shown to be a high-affinity full agonist of $\mathrm{IP}_{3} \mathrm{R} 1$, more potent than AdA 2 in releasing $\mathrm{Ca}^{2+}$ from intracellular stores and equipotent to the same material synthesized via a totally chiral route. ${ }^{35}$ InsAdA is the most potent simple $\mathrm{IP}_{3} \mathrm{R}$ agonist known and provides a novel structural template for further exploitation of potential $\mathrm{IP}_{3} \mathrm{R}$ agonists/antagonists. In particular, future synthetic elaboration of the axial hydroxyl of InsAdA could provide high potency ligands that may directly target the IBC cleft and thus offer a novel approach to ligand design not achievable with AdA. A full understanding of the activity of InsAdA must ideally await the synthesis of further members of this new structural series but, most encouragingly, the corresponding D-chiro-inositol ribophostin analogue (Figure 1, compound 4a) has already shown unusually high potency in comparison to ribophostin, its disaccharide counterpart. ${ }^{36}$

\section{EXPERIMENTAL SECTION}

Materials for Biological Analyses. HEK-293 cells in which the genes for all three $\mathrm{IP}_{3} \mathrm{R}$ subtypes had been disrupted using the CRISPR-Cas9 technique (HEK-3KO) ${ }^{2}$ were from 
Kerafast (Boston). Dulbecco's modified Eagle's medium/ nutrient mixture F-12 with GlutaMAX (DMEM/F-12 GlutaMAX) and Mag-fluo-4 AM were purchased from Thermo Fisher. G418 was from Formedium (Norfolk, U.K.). TransITLT1 transfection reagent was from Geneflow (Elmhurst, Lichfield, U.K.). Most chemicals and fetal bovine serum (FBS) were from Sigma-Aldrich (Gillingham, U.K.). $\mathrm{IP}_{3}$ was from Enzo (Exeter, U.K.) and $\left[{ }^{3} \mathrm{H}\right]-\mathrm{IP}_{3}$ was from PerkinElmer. Cyclopiazonic acid (CPA) was from Tocris (Bristol, U.K.). Half-area 96-well black-walled plates were from Greiner.

$\left[{ }^{3} \mathrm{H}\right]-\mathrm{IP}_{3}$ Binding. Cerebellar membranes, which are enriched in $\mathrm{IP}_{3} \mathrm{R} 1$, were prepared from the cerebella of adult Wistar rats as previously described. ${ }^{94}$ Equilibrium competition binding assays $\left(4{ }^{\circ} \mathrm{C}, 5 \mathrm{~min}\right)$ were performed in medium (500 $\mu \mathrm{L}$ ) comprising $50 \mathrm{mM}$ Tris, $1 \mathrm{mM}$ ethylenediaminetetraacetic acid (EDTA), pH 8.3 with ${ }^{3} \mathrm{H}-\mathrm{IP}_{3}(19.3 \mathrm{Ci} / \mathrm{mmol}, 1.5 \mathrm{nM})$, cerebellar membranes, and competing ligands. ${ }^{94}$ Bound and free ligands were separated by centrifugation $(20000 \mathrm{~g}, 5 \mathrm{~min}$, $4{ }^{\circ} \mathrm{C}$ ). Nonspecific binding, determined by the addition of 10 $\mu \mathrm{M} \mathrm{IP}{ }_{3}$ or by extrapolation of competition curves to infinite $\mathrm{IP}_{3}$ concentration, was $<10 \%$ of total binding.

Cell Culture and Transfection. HEK cells were cultured in DMEM/F-12 GlutaMAX medium supplemented with $10 \%$ FBS at $37{ }^{\circ} \mathrm{C}$ in $95 \%$ air and $5 \% \mathrm{CO}_{2}$. Cells were passaged or used for experiments when they reached confluence. HEK cells expressing only $\mathrm{IP}_{3} \mathrm{R} 1$ ( $\mathrm{HEK}-\mathrm{IP}_{3} \mathrm{R} 1$ cells) were generated by transfecting HEK-3KO cells with the gene encoding rat $\mathrm{IP}_{3} \mathrm{R} 1$ (lacking the S1 splice site) cloned into pcDNA3.1(-)/MycHis B plasmid using TransIT-LT1 reagent following the manufacturer's instructions. To generate stable cell lines, cells were passaged $48 \mathrm{~h}$ after transfection in a medium with G418 $(1 \mathrm{mg} / \mathrm{mL})$ and the selection was maintained for 2 weeks. Monoclonal cell lines were selected by plating cells ( $\sim 1$ cell/ well) into 96-well plates in a medium containing G418 (1 mg/ $\mathrm{mL}$ ). After 4 days, wells with only one cell were identified, and cells were grown to confluence. After expansion, expression of $\mathrm{IP}_{3} \mathrm{R} 1$ was confirmed by western blotting using an antibody specific for $\mathrm{IP}_{3} \mathrm{R} 1$. $^{94}$

$\mathrm{Ca}^{2+}$ Release from Intracellular Stores. Mag-fluo 4, a low-affinity fluorescent $\mathrm{Ca}^{2+}$ indicator, was used to monitor free $\left[\mathrm{Ca}^{2+}\right]$ within the ER lumen ${ }^{93}$ of HEK-IP ${ }_{3} \mathrm{R} 1$ cells. Cells were loaded with an indicator by incubating cells with Magfluo $4 \mathrm{AM}\left(20 \mu \mathrm{M}, 60 \mathrm{~min}, 22{ }^{\circ} \mathrm{C}\right)$ in $N$-(2-hydroxyethyl)piperazine- $N$-ethanesulfonic acid (HEPES)-buffered saline (HBS; $135 \mathrm{mM} \mathrm{NaCl}, 5.9 \mathrm{mM} \mathrm{KCl}, 11.6 \mathrm{mM}$ HEPES, 1.5 $\mathrm{mM} \mathrm{CaCl}, 11.5 \mathrm{mM}$ glucose, $1.2 \mathrm{mM} \mathrm{MgCl}_{2}, \mathrm{pH} 7.3$ ) as described. ${ }^{95}$ After washing and permeabilization with saponin $\left(10 \mu \mathrm{g} / \mathrm{mL}, 37^{\circ} \mathrm{C}, 2-3 \mathrm{~min}\right)$ in $\mathrm{Ca}^{2+}$-free cytosol-like medium $\left(\mathrm{Ca}^{2+}\right.$-free $\left.\mathrm{CLM}\right)$, cells were centrifuged $(650 \mathrm{~g}, 3 \mathrm{~min})$ and incubated for $7 \mathrm{~min}$ in $\mathrm{Ca}^{2+}$-free CLM to ensure stores were fully depleted of $\mathrm{Ca}^{2+}$. Cells were further centrifuged $(650 \mathrm{~g}, 3$ min) and resuspended in $\mathrm{Mg}^{2+}$-free CLM supplemented with $\mathrm{CaCl}_{2}$ to give a final free $\left[\mathrm{Ca}^{2+}\right]$ of $220 \mathrm{nM}$ after the addition of $1.5 \mathrm{mM} \mathrm{MgATP}$. $\mathrm{Ca}^{2+}$-free CLM comprised $20 \mathrm{mM} \mathrm{NaCl}, 140$ $\mathrm{mM} \mathrm{KCl}, 1 \mathrm{mM}$ ethylene glycol-bis ( $\beta$-aminoethyl ether)$N, N, N^{\prime}, N^{\prime}$-tetraacetic acid (EGTA), $20 \mathrm{mM}$ piperazine- $N, N^{\prime}$ bis(2-ethanesulfonic acid) (PIPES), and $2 \mathrm{mM} \mathrm{MgCl}_{2}, \mathrm{pH} 7.0$. Cells $\left(\sim 3 \times 10^{6} /\right.$ well $)$ were attached to poly-L-lysine-coated 96-well black-walled plates (Greiner Bio-One, Stonehouse, U.K.), and fluorescence (excitation and emission at 485 and $520 \mathrm{~nm}$, respectively) was recorded at intervals of $1.44 \mathrm{~s}$ using a FlexStation III plate reader (Molecular Devices, Sunnyvale,
CA). $\operatorname{MgATP}(1.5 \mathrm{mM})$ was added to initiate $\mathrm{Ca}^{2+}$ uptake, and when the ER had loaded to steady state ( $2.5 \mathrm{~min})$, cyclopiazonic acid (CPA, $10 \mu \mathrm{M})$ was added to inhibit the ER $\mathrm{Ca}^{2+}$ pump. $\mathrm{IP}_{3}$ and related ligands were added after a further $60 \mathrm{~s}$. The amount of $\mathrm{Ca}^{2+}$ released was calculated as a percentage of the fluorescence signal from fully loaded stores $\left(F_{\text {full }}\right)$ minus the signal from nonloaded stores $\left(F_{\text {full }}-F_{\text {empty }}\right)$.

Chemistry. Chemical reagents were purchased from either Sigma-Aldrich (Gillingham, U.K.) or Alfa Aesar (Heysham, U.K.). AR-grade solvents and anhydrous solvents were purchased from Sigma-Aldrich (Gillingham, U.K.) or Fisher Scientific (Loughborough, U.K.) and used as supplied unless specified individually. Superdry DCM and MeCN were prepared by distillation over $\mathrm{CaH}_{2}$ and stored over $3 \AA$ molecular sieves. ( \pm )-1,2:4,5-Di-O-isopropylidene-myo-inositol (21) was synthesized from myo-inositol following a literature process. ${ }^{40,41}$ The ribose analogue $\mathbf{2 8}$ was prepared using methods reported previously. ${ }^{35}$ Analytical thin-layer chromatography (TLC) was performed using precoated plates (Merck aluminum sheets silica $60 \mathrm{~F}_{254}$ ) and visualized under a UV lamp $(254 \mathrm{~nm})$ and/or by staining in ethanolic phosphomolybdic acid (PMA) or aqueous potassium permanganate $\left(\mathrm{KMnO}_{4}\right)$, followed by heating. Flash column chromatography was performed on a CombiFlash Rf Automated Flash Chromatography System (Teledyne Isco, Lincoln, NE) equipped with a UV detector using RediSep Rf disposable silica gel columns or high-performance GOLD silica columns. Analytical HPLC analyses were carried out on a Waters 2695 Alliance module equipped with a Waters 2996 photodiode array detector $(210-350 \mathrm{~nm})$. The chromatographic system consisted of a Hichrom Guard Column for HPLC and a Phenomenex Synergi $4 \mu$ m MAX-RP 80 A column $(150 \times 4.60$ $\mathrm{mm}^{2}$ ), eluted at $1 \mathrm{~mL} / \mathrm{min}$ with $0.05 \mathrm{M} \mathrm{TEAB}-\mathrm{MeCN}$ (95:5 $\rightarrow 35: 65 \mathrm{v} / \mathrm{v}$ ) over $15 \mathrm{~min}$. Semipreparative HPLC purifications were carried out on a Waters 2525 Binary Gradient Module with flex inject equipped with a Waters 2487 dual-wavelength detector. The chromatographic system consisted of a Security Guard Column for HPLC and a Phenomenex Gemini $5 \mu \mathrm{m} \mathrm{C18} 110 \AA$ column $(250 \times 10$ $\mathrm{mm}^{2}$ ), eluted at $5 \mathrm{~mL} / \mathrm{min}$ with $0.1 \mathrm{M} \mathrm{TEAB}-\mathrm{MeCN}(95: 5 \rightarrow$ 35:65 v/v) over $25 \mathrm{~min} .{ }^{1} \mathrm{H} \mathrm{NMR},{ }^{13} \mathrm{C} \mathrm{NMR}$, and ${ }^{31} \mathrm{P}$ NMR spectra were recorded on a Bruker AVIII HD 400 spectrometer at 400,100 , and $162 \mathrm{MHz}$, respectively. ${ }^{1} \mathrm{H}$, ${ }^{13} \mathrm{C}$, and ${ }^{31} \mathrm{P}$ NMR spectra of compound 5 were recorded with a Bruker Avance III HD $500 \mathrm{MHz}$ Spectrometer at 500, 126, and $202 \mathrm{MHz}$, respectively. Chemical shifts are reported in parts per million (ppm) relative to the solvent residual peaks as internal standards. ( ${ }^{1} \mathrm{H}$ NMR: $\mathrm{CDCl}_{3} 7.26 \mathrm{ppm}$; acetone- $d_{6}$ $2.05 \mathrm{ppm}$; dimethyl sulfoxide (DMSO)- $d_{6} 2.50 \mathrm{ppm}$; methanol- $d_{4} 3.31$ ppm; $\mathrm{D}_{2} \mathrm{O}$ 4.79. ${ }^{13} \mathrm{C}$ NMR: $\mathrm{CDCl}_{3} 77.16$ ppm; acetone- $d_{6} 29.84 \mathrm{ppm}$; DMSO- $\left.d_{6} 39.52 \mathrm{ppm}\right)$. All NMR data were collected at $23{ }^{\circ} \mathrm{C}$. High-resolution time-of-flight mass spectra were obtained on an Agilent single quadrupole spectrometer with CTC-PAL autosampler or a Bruker Daltonics micrOTOF mass spectrometer using electrospray ionization (ESI).

$D L-1,2: 4,5-D i-O-i s o p r o p y l i d e n e-6-0-p-m e t h o x y b e n z y l-$ myo-inositol (22). To a mixture of 1 -( $p$-toluenesulfonyl)imidazole (4.16 g, $18.7 \mathrm{mmol})$ and $21(4.8 \mathrm{~g}, 18.5 \mathrm{mmol})$ in DMF $(20 \mathrm{~mL})$ was added CsF $(3.372 \mathrm{~g}, 22.2 \mathrm{mmol})$. The mixture was stirred at rt under argon for $18 \mathrm{~h}$ and evaporated in vacuo. The resulting syrup was partitioned between $\mathrm{CH}_{2} \mathrm{Cl}_{2}$ $(400 \mathrm{~mL})$ and water $(400 \mathrm{~mL})$, and the organic layer was 
filtered through a bed of celite and evaporated to provide a white solid $(6.91 \mathrm{~g})$ that was identified by ${ }^{1} \mathrm{H}$ NMR as a mixture of monotosylate (yield 74\%) and ditosylate (yield $12 \%)$. The mixture was dissolved in DMF (40 mL). NaH (95\%, $413 \mathrm{mg}, 16.5 \mathrm{mmol}$ ) was added, and the mixture was stirred at $0{ }^{\circ} \mathrm{C}$ for $30 \mathrm{~min}$. $p$-Methoxybenzyl chloride $(2.32 \mathrm{~g}$, $15.1 \mathrm{mmol}$ ) was added, and the reaction mixture was stirred at $\mathrm{rt}$ for $16 \mathrm{~h}$. Water $(200 \mathrm{~mL})$ was added to the mixture, and the solid was collected and partitioned between DCM $(200 \mathrm{~mL})$ and water $(200 \mathrm{~mL})$. The organic solution was filtered through a bed of celite, dried, and evaporated. The resulting solid was washed with EtOAc/petroleum ether (4:1) to give an off-white solid $(7.04 \mathrm{~g})$. The above-described material and magnesium powder $(6.58 \mathrm{~g}, 274.2 \mathrm{mmol})$ in $\mathrm{MeOH}(200 \mathrm{~mL})$ and DCM $(200 \mathrm{~mL})$ were stirred in a flask with a reflux condenser. After 20-30 min, the solvent temperature was increased to reflux. The mixture was stirred for another $3 \mathrm{~h}$ cooling to rt. The solvents were then evaporated to dryness to give a light-gray solid, which was suspended in DCM $(400 \mathrm{~mL})$. $\mathrm{HCl}$ solution $(0.2 \mathrm{M}, 200 \mathrm{~mL})$ was added, and the mixture was filtered through a bed of celite and washed with DCM. The organic solvent was separated from the aqueous layer, and the solvent was evaporated to give a white solid. The remaining celite/ magnesium salt mixture was air-dried overnight and further washed with DCM and dried $\left(\mathrm{MgSO}_{4}\right)$. The combined mixture was then purified by flash column chromatography (DCM to DCM/EtOAc 1:1) to afford compound 22 (4.39 g, $63 \%$ overall from 21 ). ${ }^{1} \mathrm{H}$ and ${ }^{13} \mathrm{C}$ NMR data were identical to the previously reported data for the material prepared by the chiral route. $^{35}$

DL-3-O-Trifluoromethylsulfonyl-6-O-p-methoxybenzyl1,2:4,5-di-O-isopropylidene-myo-inositol (23). Compound 22 (4.39 g, $11.5 \mathrm{mmol})$ was dissolved in $\mathrm{CH}_{2} \mathrm{Cl}_{2}(55 \mathrm{~mL})$ and pyridine $(5 \mathrm{~mL})$ and cooled to $0{ }^{\circ} \mathrm{C}$. Trifluoromethane sulfonic anhydride $\left(13.8 \mathrm{~mL}, 13.8 \mathrm{mmol}, 1 \mathrm{M}\right.$ in $\left.\mathrm{CH}_{2} \mathrm{Cl}_{2}\right)$ was added dropwise. The reaction mixture was stirred for $30 \mathrm{~min}$ at $0{ }^{\circ} \mathrm{C}$ and then warmed up to $\mathrm{rt}$ for $2 \mathrm{~h}$. The mixture was diluted with $\mathrm{CH}_{2} \mathrm{Cl}_{2}(200 \mathrm{~mL})$, washed with water $(200 \mathrm{~mL})$, and brine was added $(20 \mathrm{~mL})$. The organic layer was dried by filtration through solid $\mathrm{NaCl}$ and concentrated in vacuo to give compound 23 as a pale beige amorphous solid (5.72 g, 97\%). ${ }^{1} \mathrm{H}$ and ${ }^{13} \mathrm{C}$ NMR data were identical to the previously reported data for the material prepared by the chiral route. ${ }^{35}$

3-O- $\left[2^{\prime}, 3^{\prime}: 5^{\prime}, 6^{\prime}-O-D i i s o p r o p y l i d e n e-4^{\prime}-O-(p-m e t h o x y b e n-\right.$ zyl)-1"-DL-chiro-inosityl]-5-O-benzyl- $\beta$-D-ribofuranose-1,2pent-4-enyl orthobenzoate $(\mathbf{2 9 a}, \mathbf{2 9 b})$. To a solution of $\mathbf{2 8} \mathbf{8}^{35}$ $(740 \mathrm{mg}, 1.79 \mathrm{mmol})$ in dry THF $(3 \mathrm{~mL})$ was added dry hexamethylphosphoramide $(8 \mathrm{~mL})$, followed by $\mathrm{NaH}(90 \mathrm{mg}$, $95 \%, 3.6 \mathrm{mmol})$. The mixture was stirred under argon at $\mathrm{rt}$ for $20 \mathrm{~min}$ and cooled to $0{ }^{\circ} \mathrm{C}$. ( \pm )-1,2:4,5-Di-O-isopropylidene6-O-p-methoxybenzyl-3-O-trifluoromethane sulfonyl-myo-inositol $( \pm-23,1.2 \mathrm{~g}, 2.34 \mathrm{mmol})$ was added, and the mixture was stirred at room temperature for $12 \mathrm{~h}$ and concentrated in vacuo. The mixture was then partitioned between ethyl ether $(80 \mathrm{~mL})$ and saturated ammonium chloride solution $(60 \mathrm{~mL})$. The organic solution was washed with brine, dried over $\mathrm{Na}_{2} \mathrm{SO}_{4}$, and concentrated. The crude product was purified using a Combiflash and eluted with a solvent gradient of petroleum ether to $20 \% \mathrm{EtOAC} /$ petroleum ether to give a clear oil. (1.1 g, 79\%). ${ }^{1} \mathrm{H}$ NMR indicated the two diastereoisomers were in a $1: 1$ ratio. ${ }^{1} \mathrm{H}$ NMR $(400 \mathrm{MHz}$, $\left.\mathrm{CDCl}_{3}\right) \delta 7.62-7.67(\mathrm{~m}, 2 \times 2 \mathrm{H}), 7.25-7.36(\mathrm{~m}, 2 \times 10 \mathrm{H})$, $6.86(\mathrm{dt}, 2 \times 2 \mathrm{H}, J=8.5,2.2 \mathrm{~Hz}), 6.08(\mathrm{~d}, 1 \mathrm{H}, J=4.2 \mathrm{~Hz})$, $5.99(\mathrm{~d}, 1 \mathrm{H}, J=4.1 \mathrm{~Hz}), 5.77(\mathrm{~m}, 2 \times 1 \mathrm{H}), 5.02(\mathrm{dd}, 1 \mathrm{H}, J=$ $4.3,1.9 \mathrm{~Hz}), 4.97(\mathrm{dd}, 1 \mathrm{H}, J=4.6,2.0 \mathrm{~Hz}), 4.93-4.96(\mathrm{~m}, 2 \times$ $1 \mathrm{H}), 4.90-4.93(\mathrm{~m}, 2 \times 1 \mathrm{H}), 4.76(\mathrm{~s}, 2 \mathrm{H}), 4.74(\mathrm{~s}, 2 \mathrm{H}), 4.60$ $(\mathrm{d}, 1 \mathrm{H}, J=12.2 \mathrm{~Hz}), 4.51(\mathrm{~s}, 2 \mathrm{H}), 4.46(\mathrm{~d}, 1 \mathrm{H}, J=12.1 \mathrm{~Hz})$, $4.32-4.39(\mathrm{~m}, 2 \times 2 \mathrm{H}), 4.23(\mathrm{t}, 1 \mathrm{H}, J=2 \mathrm{~Hz}), 4.09-4.21(\mathrm{~m}$, $1 \mathrm{H}+2 \times 2 \mathrm{H}), 4.00(\mathrm{dd}, 1 \mathrm{H}, J=9.3,4.9 \mathrm{~Hz}), 3.92(\mathrm{t}, 1 \mathrm{H}, J=$ $10.0 \mathrm{~Hz}), 3.80($ br s, $2 \times 3 \mathrm{H}), 3.74(\mathrm{t}, 1 \mathrm{H}, J=2.7 \mathrm{~Hz}), 3.71(\mathrm{t}$, $1 \mathrm{H}, J=2.8 \mathrm{~Hz}), 3.57-3.66(\mathrm{~m}, 2 \times 2 \mathrm{H}), 3.52(\mathrm{dd}, 1 \mathrm{H}, J=11$, $5.5 \mathrm{~Hz}), 3.49(\mathrm{dd}, 1 \mathrm{H}, J=11.5,5.0 \mathrm{~Hz}), 3.31-3.43(\mathrm{~m}, 2 \times$ $2 \mathrm{H}), 2.09(\mathrm{~m}, 2 \times 2 \mathrm{H}), 1.59-1.69(\mathrm{~m}, 2 \times 2 \mathrm{H}), 1.56(\mathrm{~s}, 3 \mathrm{H})$, $1.48(\mathrm{~s}, 3 \mathrm{H}), 1.42(\mathrm{~s}, 3 \mathrm{H}), 1.36(\mathrm{~s}, 3 \mathrm{H}), 1.35(\mathrm{~s}, 3 \mathrm{H}), 1.33$ (s, $3 \mathrm{H}), 1.30(\mathrm{~s}, 3 \mathrm{H}), 1.28(\mathrm{~s}, 3 \mathrm{H})$. HRMS-ESI $(\mathrm{m} / \mathrm{z})$ required for $[\mathrm{M}+\mathrm{H}]^{+} \mathrm{C}_{44} \mathrm{H}_{55} \mathrm{O}_{12}$ 775.3688, found 775.3712.

6-Chloro-9-\{2'-O-benzoyl-5'-O-benzyl-3'-O-[2", $3^{\prime \prime}: 5^{\prime \prime}, 6^{\prime \prime}$ di-O-isopropylidene-4" -O-(p-methoxybenzyl)-1" -DL-chiro-inosityl]- $\beta$-D-ribofuranosyl\}purine (30a, 30b). 6-Chloro-9-(trimethylsilyl)-9H-purine was prepared by refluxing 6-chloropurine $(284 \mathrm{mg}, 1.8 \mathrm{mmol})$ in hexamethyldisilazane $(8 \mathrm{~mL})$ for $1.5 \mathrm{~h}$, followed by concentration in vacuo. The yellow residue was mixed with acetonitrile $(4 \mathrm{~mL})$ and added to a solution of the diastereoisomers $29 \mathrm{a}$ and $29 \mathrm{~b}(1.0 \mathrm{~g}, 1.3 \mathrm{mmol})$ in acetonitrile $(4 \mathrm{~mL})$ at $0{ }^{\circ} \mathrm{C}$. The mixture was stirred over molecular sieves ( $3 \AA$, $500 \mathrm{mg}$ ) at $0{ }^{\circ} \mathrm{C}$ for $20 \mathrm{~min}$. A solution of $\mathrm{Yb}(\mathrm{OTf})_{3}(360 \mathrm{mg}, 0.58 \mathrm{mmol})$ and $N$-iodosuccinimide $(450 \mathrm{mg}, 2 \mathrm{mmol})$ in acetonitrile $(10 \mathrm{~mL})$ was also stirred with molecular sieves ( $3 \AA, 500 \mathrm{mg}$ ) at room temperature for 20 $\min$. The two suspensions were mixed and stirred under argon at room temperature for $24 \mathrm{~h}$. DCM $(50 \mathrm{~mL})$ was added, and the mixture was partitioned between DCM $(100 \mathrm{~mL})$ and sodium bisulfate solution $(4 \%, 60 \mathrm{~mL})$. The organic solution was washed with brine, dried over $\mathrm{Na}_{2} \mathrm{SO}_{4}$, and concentrated. The crude product was purified with a CombiFlash and eluted with a solvent gradient of DCM to $20 \% \mathrm{EtOAC} / \mathrm{DCM}$ to give a white foamy product $(0.78 \mathrm{~g}, 78 \%) .{ }^{1} \mathrm{H}$ NMR $(400 \mathrm{MHz}$, $\left.\mathrm{CD}_{3} \mathrm{COCD}_{3}\right) \delta 8.76(\mathrm{~s}, 1 \mathrm{H}), 8.73(\mathrm{~s}, 1 \mathrm{H}), 8.69(\mathrm{~s}, 2 \times 1 \mathrm{H})$, $8.12(\mathrm{dd}, 2 \mathrm{H}, J=8.2,1.2 \mathrm{~Hz}), 8.06(\mathrm{dd}, 2 \mathrm{H}, J=8.2,1.4 \mathrm{~Hz})$, 7.65 (ddd, $2 \times 1 \mathrm{H}, J=8.6,4.9,2.4 \mathrm{~Hz}), 7.50(\mathrm{td}, 2 \times 2 \mathrm{H}, J=$ $7.8,1.9 \mathrm{~Hz}), 7.44(\mathrm{t}, 2 \times 2 \mathrm{H}, J=7.0 \mathrm{~Hz}), 7.38(\mathrm{td}, 2 \times 2 \mathrm{H}, J=$ 7.8, 7.3, $1.8 \mathrm{~Hz}), 7.32(\mathrm{~m}, 1 \mathrm{H}), 7.28(\mathrm{~m}, 1+2 \times 2 \mathrm{H}), 6.89(\mathrm{dd}$, $2 \times 2 \mathrm{H}, J=8.6,1.8 \mathrm{~Hz}), 6.62(\mathrm{dd}, 2 \times 1 \mathrm{H}, J=6.7,5.0 \mathrm{~Hz})$, $6.29(\mathrm{t}, 1 \mathrm{H}, J=4.6 \mathrm{~Hz}), 6.17(\mathrm{t}, 1 \mathrm{H}, J=5.5 \mathrm{~Hz}), 5.21(\mathrm{t}, 1 \mathrm{H}, J$ $=5.3 \mathrm{~Hz}), 4.96(\mathrm{dd}, 1 \mathrm{H}, J=5.0,3.1 \mathrm{~Hz}), 4.76(\mathrm{~d}, 2 \times 1 \mathrm{H}, J=$ $12.2 \mathrm{~Hz}), 4.69-4.73(\mathrm{~m}, 2 \times 1 \mathrm{H}), 4.67(\mathrm{~m}, 1 \mathrm{H}), 4.65(\mathrm{~s}, 2 \mathrm{H})$, $4.64(\mathrm{~s}, 2 \mathrm{H}), 4.59(\mathrm{dt}, 1 \mathrm{H}, J=5.8,3.1 \mathrm{~Hz}), 4.47(\mathrm{~d}, 2 \times 1 \mathrm{H}, J$ $=4.8 \mathrm{~Hz}), 4.42(\mathrm{t}, 1 \mathrm{H}, J=2.4 \mathrm{~Hz}), 4.38(\mathrm{dd}, 1 \mathrm{H}, J=5.6,2.1$ $\mathrm{Hz}), 4.12(\mathrm{t}, 1 \mathrm{H}, J=5.8 \mathrm{~Hz}), 4.08(\mathrm{t}, 1 \mathrm{H}, J=6.0 \mathrm{~Hz}), 4.00(\mathrm{td}$, $2 \times 1 \mathrm{H}, J=11.0,3.1 \mathrm{~Hz}), 3.88-3.96(\mathrm{~m}, 2 \times 2 \mathrm{H}), 3.78(\mathrm{~s}, 2 \times$ $3 \mathrm{H}), 3.68-3.75(\mathrm{~m}, 2 \times 1 \mathrm{H}), 3.60(\mathrm{ddd}, 2 \times 1 \mathrm{H}, J=10.2,6.2$, $1.2 \mathrm{~Hz}), 1.40$ (s, 3H), 1.38 (s, 3H), 1.33 (s, 3H), 1.29 (s, 3H), $1.26(\mathrm{~s}, 3 \mathrm{H}), 1.24(\mathrm{~s}, 3 \mathrm{H}), 1.10(\mathrm{~s}, 3 \mathrm{H}), 1.00(\mathrm{~s}, 3 \mathrm{H})$. HRMSESI $(m / z)$ required for $[\mathrm{M}+\mathrm{H}]^{+} \mathrm{C}_{44} \mathrm{H}_{48} \mathrm{ClN}_{4} \mathrm{O}_{11}$ 843.3003, found 843.3026 .

6-Chloro-9-\{2'-O-benzoyl-5'-O-benzyl-3'-O-[5" , 6"-O-isopropylidene-4"-O-(p-methoxybenzyl)- $1^{\prime \prime}$-D-chiro-inosityl]- $\beta$ D-ribofuranosyl\}purine (31) and 6-Chloro-9-\{2'-O-benzoyl5'-O-benzyl-3'-O-[5", 6"-O-isopropylidene-4" -O-(p-methoxybenzyl)-1"-L-Chiro-inosityl]- $\beta$-D-ribofuranosyl\}purine (32). To a solution of the diastereoisomers $30 \mathrm{a}$ and $30 \mathrm{~b}(1.2 \mathrm{~g}$, $1.45 \mathrm{mmol})$ in anhydrous DCM $(25 \mathrm{~mL})$ was added ethylene glycol (144 mg, $2.3 \mathrm{mmol}$ ), followed by $p$ TSA $(25 \mathrm{mg})$. The mixture was stirred at room temperature for $30 \mathrm{~min}$ and partitioned between DCM $(50 \mathrm{~mL})$ and $5 \% \mathrm{NaHCO}_{3}(50$ $\mathrm{mL}$ ). The organic solution was washed with brine, dried over 
$\mathrm{Na}_{2} \mathrm{SO}_{4}$, and concentrated to give a foam $(1.1 \mathrm{~g})$. The crude product was divided into $300 \mathrm{mg}$ portions, and each portion was subjected to repeated flash chromatography and eluted with a gradient solvent of DCM to $15 \%$ acetone/DCM. Compound 31, the less polar product on TLC ( $40 \%$ acetone/ DCM), was obtained as a clear oil (480 mg, 42\%). The compound was identified as the D-chiro-inositol derivative (31) by comparing the NMR spectra with those of the same material prepared by the chiral route. ${ }^{34}[\alpha]_{\mathrm{D}}^{23}=+4.0^{\circ}(c=0.5$; $\left.\mathrm{CH}_{3} \mathrm{CN}\right) .{ }^{1} \mathrm{H}$ NMR $\left(400 \mathrm{MHz}, \mathrm{CD}_{3} \mathrm{COCD}_{3}\right) \delta 8.74(\mathrm{~s}, 1 \mathrm{H})$, $8.71(\mathrm{~s}, 1 \mathrm{H}), 7.99-8.15(\mathrm{~m}, 2 \mathrm{H}), 7.63$ (ddd, $1 \mathrm{H}, J=7.2,1.2$ $\mathrm{Hz}), 7.46-7.53(\mathrm{~m}, 2 \mathrm{H}), 7.39-7.44(\mathrm{~m}, 2 \mathrm{H}), 7.34-7.38(\mathrm{~m}$, $2 \mathrm{H}), 7.26-7.33(\mathrm{~m}, 3 \mathrm{H}), 6.87(\mathrm{dt}, 2 \mathrm{H}, J=8.6,2.3 \mathrm{~Hz}), 6.60$ $(\mathrm{d}, 1 \mathrm{H}, J=4.5 \mathrm{~Hz}), 6.15(\mathrm{t}, 1 \mathrm{H}, J=4.8 \mathrm{~Hz}), 5.16(\mathrm{t}, 1 \mathrm{H}, J=$ $5.0 \mathrm{~Hz}), 4.76(\mathrm{~d}, 1 \mathrm{H}, J=11.4 \mathrm{~Hz}), 4.76(\mathrm{~d}, 1 \mathrm{H}, J=12.0 \mathrm{~Hz})$, $4.70(\mathrm{dd}, 1 \mathrm{H}, J=12.0,7.5 \mathrm{~Hz}), 4.64(\mathrm{~d}, 1 \mathrm{H}, J=11.5 \mathrm{~Hz}), 4.57$ $(\mathrm{dt}, 1 \mathrm{H}, J=5.0,3.1 \mathrm{~Hz}), 4.44(\mathrm{dd}, 1 \mathrm{H}, J=6.7,5.3 \mathrm{~Hz}), 4.25$ $(\mathrm{dd}, 1 \mathrm{H}, J=8.2,6.6 \mathrm{~Hz}), 4.10(\mathrm{~d}, 1 \mathrm{H}, J=3.9 \mathrm{~Hz}), 4.08(\mathrm{dd}$, $1 \mathrm{H}, J=5.3,2.6 \mathrm{~Hz}), 3.99(\mathrm{dd}, 1 \mathrm{H}, J=10.9,2.9 \mathrm{~Hz}), 3.92(\mathrm{dd}$, $1 \mathrm{H}, J=10.5 .0,3.5 \mathrm{~Hz}$ ), $3.92(\mathrm{~d}, 1 \mathrm{H}, J=4.0 \mathrm{~Hz}), 3.80(\mathrm{ddd}$, $1 \mathrm{H}, J=5.6,4.0,2.6 \mathrm{~Hz}), 3.78(\mathrm{~s}, 3 \mathrm{H}), 3.69-3.75(\mathrm{~m}, 1 \mathrm{H})$, $3.39(\mathrm{t}, 1 \mathrm{H}, J=8.1 \mathrm{~Hz}), 1.40(\mathrm{~s}, 3 \mathrm{H}), 1.27(\mathrm{~s}, 3 \mathrm{H})$. HRMS-ESI $(\mathrm{m} / z)$ required for $[\mathrm{M}+\mathrm{H}]^{+} \mathrm{C}_{41} \mathrm{H}_{44} \mathrm{ClN}_{4} \mathrm{O}_{11}$ 803.2690, found 803.2718. Compound 32, the more polar product on TLC (40\% acetone/DCM), was obtained as a clear oil $(500 \mathrm{mg}$, 43\%). ${ }^{1} \mathrm{H} \mathrm{NMR}\left(400 \mathrm{MHz}, \mathrm{CD}_{3} \mathrm{COCD}_{3}\right) \delta 8.73(\mathrm{~s}, 1 \mathrm{H}), 8.71$ (s, $1 \mathrm{H}), 7.99-8.14(\mathrm{~m}, 2 \mathrm{H}), 7.64(\mathrm{ddd}, 1 \mathrm{H}, J=7.5,1.3 \mathrm{~Hz})$, 7.57-7.54 (m, 2H), 7.42-7.46 (m, 2H), 7.36-7.40 (m, 2H), $7.28-7.35(\mathrm{~m}, 2 \mathrm{H}), 7.27(\mathrm{~d}, 1 \mathrm{H}, J=8.9 \mathrm{~Hz}), 6.80-6.91(\mathrm{~m}$, $2 \mathrm{H}), 6.61(\mathrm{~d}, 1 \mathrm{H}, J=5.7 \mathrm{~Hz}), 6.07(\mathrm{t}, 1 \mathrm{H}, J=5.4 \mathrm{~Hz}), 5.05$ $(\mathrm{dd}, 1 \mathrm{H}, J=5.2,3.7 \mathrm{~Hz}), 4.72(\mathrm{~d}, 2 \mathrm{H}, J=11.6 \mathrm{~Hz}), 4.71(\mathrm{~s}$, $2 \mathrm{H}), 4.67(\mathrm{~d}, 1 \mathrm{H}, J=3.3 \mathrm{~Hz}), 4.60(\mathrm{~d}, 1 \mathrm{H}, J=11.4 \mathrm{~Hz}), 4.24-$ $4.27(\mathrm{~m}, 1 \mathrm{H}), 4.22(\mathrm{~d}, 1 \mathrm{H}, J=5.7 \mathrm{~Hz}), 4.21(\mathrm{~d}, 1 \mathrm{H}, J=5.7$ $\mathrm{Hz}), 4.14(\mathrm{dd}, 1 \mathrm{H}, J=3.5,1.9 \mathrm{~Hz}), 4.04(\mathrm{dd}, 1 \mathrm{H}, J=7.3,5.8$ $\mathrm{Hz}), 3.99(\mathrm{dd}, 1 \mathrm{H}, J=10.5,3.1 \mathrm{~Hz}), 3.94(\mathrm{dd}, 1 \mathrm{H}, J=10.8$, $3.1 \mathrm{~Hz}), 3.78(\mathrm{~s}, 3 \mathrm{H}), 3.72-3.75(\mathrm{~m}, 2 \mathrm{H}), 1.31(\mathrm{~s}, 4 \mathrm{H}), 1.04$ $(\mathrm{s}, 3 \mathrm{H})$. HRMS-ESI $(\mathrm{m} / z)$ required for $[\mathrm{M}+\mathrm{H}]^{+}$ $\mathrm{C}_{41} \mathrm{H}_{44} \mathrm{ClN}_{4} \mathrm{O}_{11}$ 803.2690, found 803.2662.

Monobenzylation Model Reaction: DL-1,4,6-Tri-O-benzyl2,3-O-isopropylidene-myo-inositol (35) and DL-1,4,5-Tri-Obenzyl-2,3-O-isopropylidene-myo-inositol (36). To a solution of $33^{96}(200 \mathrm{mg}, 0.50 \mathrm{mmol})$ in dry $\mathrm{CH}_{3} \mathrm{CN}(25 \mathrm{~mL})$ was added $\mathrm{Bu}_{2} \mathrm{SnO}(390 \mathrm{mg}, 1.1 \mathrm{mmol})$. The mixture was refluxed in a flask equipped with a Soxhlet extractor containing molecular sieve powder ( $3 \AA$ ) under nitrogen. After $15 \mathrm{~h}$, the mixture was cooled to room temperature and concentrated to dryness in vacuo. DMF ( $5 \mathrm{~mL}$ ) was added to the residue, followed by CsF (266 mg, $1.75 \mathrm{mmol}$ ), TBAI (37 mg, 0.09 $\mathrm{mmol})$, molecular sieves ( $3 \AA, 120 \mathrm{mg})$, and $\mathrm{BnBr}(0.18 \mathrm{~mL}$, $1.47 \mathrm{mmol}$ ). The mixture was stirred at room temperature under argon for $18 \mathrm{~h}$, diluted with DCM $(50 \mathrm{~mL})$, and filtered through celite. The filtrate was washed with brine, dried over $\mathrm{Na}_{2} \mathrm{SO}_{4}$, and concentrated to give a clear oil. The crude product was subjected to flash chromatography and eluted with a gradient solvent of petroleum ether to 60\% EtOAc/ petroleum ether. Compound 35, the less polar product on TLC (50\% EtOAc/petroleum ether), was obtained as a clear oil, which turned into a waxy solid $(140 \mathrm{mg}, 57 \%) .{ }^{1} \mathrm{H}$ NMR $\left(400 \mathrm{MHz}, \mathrm{CD}_{3} \mathrm{COCD}_{3}\right) \delta 7.17-7.50(\mathrm{~m}, 15 \mathrm{H}), 4.88(\mathrm{~d}, 1 \mathrm{H}$, $J=11.9 \mathrm{~Hz}), 4.81(\mathrm{~s}, 2 \mathrm{H}), 4.79(\mathrm{~d}, 1 \mathrm{H}, J=11.7 \mathrm{~Hz}), 4.76(\mathrm{~d}$, $1 \mathrm{H}, J=10.8 \mathrm{~Hz}), 4.71(\mathrm{~d}, 1 \mathrm{H}, J=11.2 \mathrm{~Hz}), 4.53(\mathrm{dd}, 1 \mathrm{H}, J=$ 6.0, $3.7 \mathrm{~Hz}$ ), $4.22(\mathrm{~d}, 1 \mathrm{H}, J=3.7 \mathrm{~Hz}), 4.19(\mathrm{dd}, 1 \mathrm{H}, J=7.0,6.0$ $\mathrm{Hz}), 3.82(\mathrm{dd}, 1 \mathrm{H}, J=7.4,3.7 \mathrm{~Hz}), 3.73(\mathrm{t}, 1 \mathrm{H}, J=7.7 \mathrm{~Hz})$, $3.70(\mathrm{~d}, 1 \mathrm{H}, J=7.0 \mathrm{~Hz}), 3.58(\mathrm{ddd}, 1 \mathrm{H}, J=9.8,7.6,4.1 \mathrm{~Hz})$, $1.45(\mathrm{~s}, 3 \mathrm{H}), 1.33(\mathrm{~s}, 3 \mathrm{H})$. Compound 36, the more polar product on TLC (50\% EtOAc/petroleum ether), was obtained as a clear oil, which solidified into a waxy solid $(40 \mathrm{mg}, 16 \%)$. ${ }^{1} \mathrm{H}$ NMR (400 MHz, $\left.\mathrm{CD}_{3} \mathrm{COCD}_{3}\right) \delta 7.25-7.45(\mathrm{~m}, 15 \mathrm{H})$, $4.86(\mathrm{~d}, 1 \mathrm{H}, J=11 \mathrm{~Hz}), 4.85(\mathrm{~d}, 1 \mathrm{H}, J=10.8 \mathrm{~Hz}), 4.79(\mathrm{~d}$, $1 \mathrm{H}, J=11.8 \mathrm{~Hz}), 4.77(\mathrm{~s}, 2 \mathrm{H}), 4.76(\mathrm{~d}, 1 \mathrm{H}, J=11.8 \mathrm{~Hz}), 4.55$ $(\mathrm{dd}, 1 \mathrm{H}, J=5.7,3.8 \mathrm{~Hz}), 4.38(\mathrm{~d}, 1 \mathrm{H}, J=3.5 \mathrm{~Hz}), 4.22(\mathrm{dd}$, $1 \mathrm{H}, J=6.9,5.7 \mathrm{~Hz}), 4.01(\mathrm{td}, 1 \mathrm{H}, J=8.5,3.9 \mathrm{~Hz}), 3.73(\mathrm{~m}$, $2 \mathrm{H}), 3.38(\mathrm{t}, 1 \mathrm{H}, \mathrm{J}=9.3 \mathrm{~Hz}), 1.44(\mathrm{~s}, 3 \mathrm{H}), 1.31(\mathrm{~s}, 3 \mathrm{H})$. Starting material 33 was recovered as a white solid $(35 \mathrm{mg}$, $17 \%)$.

6-Chloro-9-\{2'-O-benzoyl-5'-O-benzyl-3'-O-[2" -O-benzyl$5^{\prime \prime}, 6^{\prime \prime}-O$-isopropylidene-4"-O-(p-methoxybenzyl)-1"-L-chiroinosityl]- $\beta$-D-ribofuranosyl\}purine (37) and 6-Chloro-9-\{2'O-benzoyl-5'-O-benzyl-3'-O-[3"-O-benzyl-5", 6" -O-isopropylidene-4" -O-(p-methoxy-benzyl)- $1^{\prime \prime}$-L-chiro-inosityl]- $\beta$ - $D$ ribofuranosyl\}purine (38). The title compounds were prepared from 32 using the same method as that for $\mathbf{3 5}$ and 36. Compounds $\mathbf{3 7}$ and $\mathbf{3 8}$ were obtained as clear oils (an inseparable mixture in ratio of $3: 1,58 \%$ yield). ${ }^{1} \mathrm{H}$ NMR signals are from the combination of the two regioisomers. ${ }^{1} \mathrm{H}$ NMR $\left(400 \mathrm{MHz}, \mathrm{CD}_{3} \mathrm{COCD}_{3}\right) \delta 8.74(\mathrm{~s}, 1 \mathrm{H}), 8.70(\mathrm{~s}, 1 \mathrm{H})$, $8.70(\mathrm{~s}, 0.3 \mathrm{H}), 8.68(\mathrm{~s}, 0.3 \mathrm{H}), 8.01-8.10(\mathrm{~m}, 2+0.6 \mathrm{H}), 7.60-$ $7.70(\mathrm{~m}, 1+0.3 \mathrm{H}), 7.46-7.55(\mathrm{~m}, 2+0.6 \mathrm{H}), 7.37-7.44(\mathrm{~m}$, $2+0.6 \mathrm{H}), 7.22-7.38(\mathrm{~m}, 10+3 \mathrm{H}), 6.86(\mathrm{t}, 2+0.6 \mathrm{H}, J=8.5$ $\mathrm{Hz}), 6.61(\mathrm{~d}, 1 \mathrm{H}, J=5.2 \mathrm{~Hz}), 6.58(\mathrm{~d}, 0.3 \mathrm{H}, J=5.3 \mathrm{~Hz}), 6.09$ $(\mathrm{t}, 1+0.3 \mathrm{H}, J=5.2 \mathrm{~Hz}), 5.08(\mathrm{dd}, 1 \mathrm{H}, J=5.2,4.2 \mathrm{~Hz}), 5.05$ $(\mathrm{dd}, 1+0.3 \mathrm{H}, J=5.1,4.1 \mathrm{~Hz}), 4.66-4.85(\mathrm{~m}, 5+1.5 \mathrm{H})$, $4.51-4.61(\mathrm{~m}, 2+0.6 \mathrm{H}), 4.41(\mathrm{~d}, 1 \mathrm{H}, J=4.2 \mathrm{~Hz}), 4.37(\mathrm{~d}$, $0.3 \mathrm{H}, J=4.0 \mathrm{~Hz}), 4.27(\mathrm{dd}, 1 \mathrm{H}, J=6.2,4.0 \mathrm{~Hz}), 4.22(\mathrm{dd}$, $0.3 \mathrm{H}, J=4.3,2.4 \mathrm{~Hz}), 4.16(\mathrm{dd}, 1+0.3 \mathrm{H}, J=7.4,6.1 \mathrm{~Hz})$, 4.07-4.13 (m, $1+0.3 \mathrm{H}), 3.86-3.99(\mathrm{~m}, 3+1 \mathrm{H}), 3.77(\mathrm{~s}$, $1 \mathrm{H}), 3.77(\mathrm{~s}, 3 \mathrm{H}), 3.69$ (dd, $0.3 \mathrm{H}, J=7.1,2.4 \mathrm{~Hz}), 3.59-3.65$ $(\mathrm{m}, 1+0.3 \mathrm{H}), 3.49(\mathrm{dd}, 1 \mathrm{H}, J=8.6,7.5 \mathrm{~Hz}), 3.41(\mathrm{t}, 0.3 \mathrm{H}, J=$ $8.1 \mathrm{~Hz}), 1.31(\mathrm{~s}, 3 \mathrm{H}), 1.30(\mathrm{~s}, 2 \mathrm{H}), 1.03(\mathrm{~s}, 3 \mathrm{H}), 1.02(\mathrm{~s}, 1 \mathrm{H})$.

6-Chloro-9-\{2'-O-benzoyl-5'-O-benzyl-3'-O-[2"-O-benzyl$5^{\prime \prime}, 6^{\prime \prime}-O$-isopropylidene-4"-O-(p-methoxybenzyl)-1"-D-chiroinosityl]- $\beta$-D-ribofuranosyl\}purine (39) and 6-Chloro-9-\{2'O-benzoyl-5'-O-benzyl-3'-O-[3"-O-benzyl-5", 6" -O-isopropylidene-4" -O-(p-methoxybenzyl)-1"-D-chiro-inosityl]- $\beta$ - $D$ ribofuranosyl\}purine (40). To a solution of diol $31(150 \mathrm{mg}$, $0.19 \mathrm{mmol})$ in anhydrous $\mathrm{CH}_{3} \mathrm{CN}(15 \mathrm{~mL})$ was added $\mathrm{Bu}_{2} \mathrm{SnO}$ (150 mg, $\left.0.60 \mathrm{mmol}\right)$. The mixture was refluxed in a flask equipped with a Soxhlet extractor containing activated molecular sieve powder $(3 \AA)$ under nitrogen. After $18 \mathrm{~h}$, the mixture was cooled to room temperature and concentrated to dryness in vacuo. DMF ( $3 \mathrm{~mL})$ was added to the residue, followed by CsF (150 mg, $0.99 \mathrm{mmol})$, TBAI $(20 \mathrm{mg}, 0.05$ $\mathrm{mmol}$ ), molecular sieves ( $3 \AA, 120 \mathrm{mg})$, and $\mathrm{BnBr}(0.1 \mathrm{~mL}$, $0.82 \mathrm{mmol})$. The mixture was stirred at room temperature under argon for $16 \mathrm{~h}$, diluted with DCM $(50 \mathrm{~mL})$, and filtered through celite. The filtrate was washed with brine, dried over $\mathrm{Na}_{2} \mathrm{SO}_{4}$, and concentrated to give a clear oil. The crude product was subjected to flash chromatography and eluted with a solvent gradient of petroleum ether to $60 \% \mathrm{EtOAc/}$ petroleum ether. Compound 39, the less polar product on TLC (50\% EtOAc/petroleum ether), was obtained as a clear oil $(43 \mathrm{mg}, 26 \%) .[\alpha]_{\mathrm{D}}{ }^{23}=-3.0^{\circ}\left(c=0.5 ; \mathrm{CH}_{3} \mathrm{CN}\right) .{ }^{1} \mathrm{H} \mathrm{NMR}$ $\left(400 \mathrm{MHz}, \mathrm{CD}_{3} \mathrm{COCD}_{3}\right) \delta 8.75(\mathrm{~s}, 1 \mathrm{H}), 8.73(\mathrm{~s}, 1 \mathrm{H}), 8.03$ (dd, $2 \mathrm{H}, J=8.4,1.3 \mathrm{~Hz}$ ), 7.62 (ddd, $1 \mathrm{H}, J=7.5,1.3 \mathrm{~Hz}$ ), $7.19-7.47(\mathrm{~m}, 14 \mathrm{H}), 6.87(\mathrm{dt}, 2 \mathrm{H}, J=8.5,2.1 \mathrm{~Hz}), 6.64(\mathrm{~d}$, $1 \mathrm{H}, J=4.8 \mathrm{~Hz}), 6.12(\mathrm{t}, 1 \mathrm{H}, J=5.0 \mathrm{~Hz}), 5.12(\mathrm{t}, 1 \mathrm{H}, J=4.9$ 
$\mathrm{Hz}), 4.77(\mathrm{~d}, 1 \mathrm{H}, J=11.4 \mathrm{~Hz}), 4.64-4.71(\mathrm{~m}, 4 \mathrm{H}), 4.50-4.57$ (m, $3 \mathrm{H}), 4.27-4.32(\mathrm{~m}, 2 \mathrm{H}), 4.08(\mathrm{dd}, 1 \mathrm{H}, J=6.4,2.2 \mathrm{~Hz})$, $4.00(\mathrm{dd}, 1 \mathrm{H}, J=10.9,2.9 \mathrm{~Hz}), 3.92(\mathrm{dd}, 1 \mathrm{H}, J=10.9,3.4$ $\mathrm{Hz}), 3.86(\mathrm{dd}, 1 \mathrm{H}, J=7.1,3.6 \mathrm{~Hz}), 3.79\left(\mathrm{~s}, 3 \mathrm{H}, \mathrm{OCH}_{3}\right), 3.65$ (dd, $1 \mathrm{H}, J=3.4,2.2 \mathrm{~Hz}), 3.43(\mathrm{dd}, 1 \mathrm{H}, J=8.8,7.0 \mathrm{~Hz}), 1.42$ $(\mathrm{s}, 3 \mathrm{H}), 1.32(\mathrm{~s}, 3 \mathrm{H})$. HRMS-ESI $(\mathrm{m} / z)$ required for $[\mathrm{M}+$ $\mathrm{H}]^{+} \mathrm{C}_{48} \mathrm{H}_{50} \mathrm{ClN}_{4} \mathrm{O}_{11}$ 893.3153, found 893.3161. Compound 40, the more polar product on TLC (50\% EtOAc/petroleum ether), was obtained as a clear oil $(52 \mathrm{mg}, 31 \%) .[\alpha]_{\mathrm{D}}{ }^{23}=$ $+4.3^{\circ}\left(c=0.4 ; \mathrm{CH}_{3} \mathrm{CN}\right) .{ }^{1} \mathrm{H}$ NMR $\left(400 \mathrm{MHz}, \mathrm{CD}_{3} \mathrm{COCD}_{3}\right) \delta$ $8.75(\mathrm{~s}, 1 \mathrm{H}), 8.71(\mathrm{~s}, 1 \mathrm{H}), 7.96-8.15(\mathrm{~m}, 2 \mathrm{H}), 7.62(\mathrm{ddd}, 1 \mathrm{H}$, $J=7.5,1.3 \mathrm{~Hz}), 7.45-7.50(\mathrm{~m}, 2 \mathrm{H}), 7.38-7.41(\mathrm{~m}, 2 \mathrm{H})$, $7.23-7.37(\mathrm{~m}, 10 \mathrm{H}), 6.85(\mathrm{dt}, 2 \mathrm{H}, J=8.9,2.1 \mathrm{~Hz}), 6.63(\mathrm{~d}$, $1 \mathrm{H}, J=4.3 \mathrm{~Hz}), 6.13(\mathrm{dd}, 1 \mathrm{H}, J=5.2,4.3 \mathrm{~Hz}), 5.18(\mathrm{t}, 1 \mathrm{H}, J=$ $5.2 \mathrm{~Hz}), 4.65-4.75(\mathrm{~m}, 3 \mathrm{H}), 4.61(\mathrm{~d}, 1 \mathrm{H}, J=11.4 \mathrm{~Hz}), 4.57$ $(\mathrm{dt}, 1 \mathrm{H}, J=5.7,3.0 \mathrm{~Hz}), 4.47(\mathrm{dd}, 1 \mathrm{H}, J=7.2,5.2 \mathrm{~Hz}), 4.46$ $(\mathrm{d}, 1 \mathrm{H}, J=11.2 \mathrm{~Hz}), 4.43(\mathrm{~d}, 1 \mathrm{H}, J=11.6 \mathrm{~Hz}), 4.32(\mathrm{t}, 1 \mathrm{H}, J=$ $8.2 \mathrm{~Hz}), 4.29$ (d, $1 \mathrm{H}, J=3.2 \mathrm{~Hz}, \mathrm{OH}), 3.91-4.02(\mathrm{~m}, 4 \mathrm{H})$, $3.76(3 \mathrm{H}, \mathrm{s}, \mathrm{OCH} 3), 3.53$ (dd, $1 \mathrm{H}, J=7.7,3.2 \mathrm{~Hz}), 3.49$ (dd, $1 \mathrm{H}, J=8.3,7.2 \mathrm{~Hz}), 1.41(\mathrm{~s}, 3 \mathrm{H}), 1.29(\mathrm{~s}, 3 \mathrm{H})$. HRMS-ESI $(m / z)$ required for $[\mathrm{M}+\mathrm{H}]^{+} \mathrm{C}_{48} \mathrm{H}_{50} \mathrm{ClN}_{4} \mathrm{O}_{11}$ 893.3153, found 893.3160. Starting material 31 was recovered as a clear oil (38 $\mathrm{mg}, 25 \%)$.

3'-O-[2"-O-Benzyl-5", 6" -O-isopropylidene-4" -O-(p-methoxybenzyl)-1"-D-chiro-inosityl]-5'-O-benzyl adenosine (41). Ammonia gas was bubbled into a solution of 39 (50 $\mathrm{mg}, 0.056 \mathrm{mmol})$ in anhydrous EtOH $(8 \mathrm{~mL})$ in a pressure tube at $0{ }^{\circ} \mathrm{C}$ for $30 \mathrm{~min}$. The tube was sealed and heated to 78 ${ }^{\circ} \mathrm{C}$. After stirring for $20 \mathrm{~h}$, the mixture was cooled to room temperature and concentrated to dryness in vacuo. The crude product was subjected to flash chromatography and eluted with a solvent gradient of DCM to $5 \% \mathrm{MeOH} / \mathrm{DCM}$. Compound 41 was obtained as a clear oil (30 mg, 61\%). $[\alpha]_{\mathrm{D}}{ }^{23}=+3.6^{\circ}\left(c=0.25, \mathrm{CH}_{3} \mathrm{CN}\right) .{ }^{1} \mathrm{H} \mathrm{NMR}(400 \mathrm{MHz}$, $\left.\mathrm{CD}_{3} \mathrm{COCD}_{3}\right) \delta 8.20(\mathrm{~s}, 1 \mathrm{H}), 8.19(\mathrm{~s}, 1 \mathrm{H}), 7.18-7.45(\mathrm{~m}$, $12 \mathrm{H}), 6.89(\mathrm{~d}, 2 \mathrm{H}, J=8.7 \mathrm{~Hz}), 6.63\left(\mathrm{~s}, 2 \mathrm{H}, \mathrm{NH}_{2}\right), 6.04(\mathrm{~d}$, $1 \mathrm{H}, J=3.6 \mathrm{~Hz}), 4.90(\mathrm{~d}, 1 \mathrm{H}, J=11.8 \mathrm{~Hz}), 4.81(\mathrm{~d}, 1 \mathrm{H}, J=9.9$ $\mathrm{Hz}), 4.78(\mathrm{~d}, 1 \mathrm{H}, J=3.8 \mathrm{~Hz}), 4.77(\mathrm{t}, 1 \mathrm{H}, J=4.3 \mathrm{~Hz}), 4.61-$ $4.73(\mathrm{~m}, 4 \mathrm{H}), 4.59-4.48(\mathrm{~m}, 2 \mathrm{H}), 4.39(\mathrm{dd}, 1 \mathrm{H}, J=5.8,3.8$ $\mathrm{Hz}), 4.30-4.17(\mathrm{~m}, 3 \mathrm{H}), 4.03(\mathrm{t}, 1 \mathrm{H}, J=8.7 \mathrm{~Hz}), 3.85(\mathrm{dd}$, $1 \mathrm{H}, J=10.9,3.3 \mathrm{~Hz}), 3.78\left(\mathrm{~s}, 3 \mathrm{H}, \mathrm{OCH}_{3}\right), 3.75-3.79(\mathrm{~m}$, $1 \mathrm{H}), 3.74(\mathrm{dd}, 1 \mathrm{H}, J=8.1,2.9 \mathrm{~Hz}$ ), 3.48 (dd, $1 \mathrm{H}, J=8.7,7.4$ $\mathrm{Hz}), 1.40(\mathrm{~s}, 3 \mathrm{H}), 1.29(\mathrm{~s}, 3 \mathrm{H}) .{ }^{13} \mathrm{C} \mathrm{NMR}(101 \mathrm{MHz}$, $\left.\mathrm{CD}_{3} \mathrm{COCD}_{3}\right) \delta 160.14,157.17,153.83,150.71,140.03$, $139.38,139.17,132.18,130.26,129.30,129.20,129.00$, $128.58,128.52,128.49,120.63,114.31,110.15,89.50,84.69$, $82.32,80.26,80.15,79.91,78.18,76.47,74.55,74.51,73.99$, 73.63, 72.77, 70.23, 55.56, 28.33, 26.30. HRMS-ESI $(\mathrm{m} / z)$ required for $[\mathrm{M}+\mathrm{H}]^{+} \mathrm{C}_{41} \mathrm{H}_{48} \mathrm{~N}_{5} \mathrm{O}_{10}$ 770.3390, found 770.3390 .

DL-1,4-Di-O-benzyl-6-O-(para-methoxybenzyl)-2,3-O-isopropylidene-myo-inositol (45) and DL-1,4-Di-O-benzyl-5-O(para-methoxybenzyl)-2,3-O-isopropylidene-myo-inositol (46). The title compounds were prepared from $33(300 \mathrm{mg}$, $0.75 \mathrm{mmol}$ ) using the same method as for compounds 35 and 36. Compound 45 was obtained as a waxy solid $(230 \mathrm{mg}, 59 \%)$ ${ }^{1} \mathrm{H}$ NMR (400 MHz, $\left.\mathrm{CD}_{3} \mathrm{COCD}_{3}\right) \delta 7.20-7.52(\mathrm{~m}, 12 \mathrm{H})$, 6.77-6.92 (m, 2H), 4.89 (d, $1 \mathrm{H}, J=11.9 \mathrm{~Hz}), 4.79(\mathrm{~d}, 1 \mathrm{H}, J=$ $11.9 \mathrm{~Hz}), 4.75(\mathrm{~d}, 1 \mathrm{H}, J=11.5 \mathrm{~Hz}), 4.73(\mathrm{~s}, 2 \mathrm{H}), 4.70(\mathrm{~d}, 1 \mathrm{H}$, $J=11.5 \mathrm{~Hz}), 4.50(\mathrm{dd}, 1 \mathrm{H}, J=6.0,3.6 \mathrm{~Hz}), 4.18(\mathrm{dd}, 1 \mathrm{H}, J=$ 7.0, $6.0 \mathrm{~Hz}), 4.14(\mathrm{~d}, 1 \mathrm{H}, J=4.2 \mathrm{~Hz}), 3.68-3.88(\mathrm{~m}, 3 \mathrm{H}), 3.77$ (s, 3H), 3.50-3.61 (m, $1 \mathrm{H}), 1.45(\mathrm{~s}, 3 \mathrm{H}), 1.33(\mathrm{~s}, 3 \mathrm{H}) \cdot{ }^{13} \mathrm{C}$ NMR (101 MHz, $\left.\mathrm{CD}_{3} \mathrm{COCD}_{3}\right) \delta 160.09,140.26,139.95$,
$132.18,130.23,129.04,128.92,128.61,128.37,128.18,128.04$ $114.32,109.98,83.13,81.80,79.89,78.45,75.13,74.87,74.28$, 73.76, 72.95, 55.51, 27.96, 26.02. Compound 46 was obtained as a waxy solid (52 mg, 13\%). ${ }^{1} \mathrm{H}$ NMR (400 $\mathrm{MHz}$, $\left.\mathrm{CD}_{3} \mathrm{COCD}_{3}\right) \delta 7.21-7.47(\mathrm{~m}, 12 \mathrm{H}), 6.73-6.92(\mathrm{~m}, 2 \mathrm{H})$, $4.85(\mathrm{~d}, 1 \mathrm{H}, J=11.8 \mathrm{~Hz}), 4.77(\mathrm{~s}, 2 \mathrm{H}), 4.70-4.81(\mathrm{~m}, 3 \mathrm{H})$, $4.54(\mathrm{dd}, 1 \mathrm{H}, J=5.7,3.8 \mathrm{~Hz}), 4.29(\mathrm{~d}, 1 \mathrm{H}, J=3.5 \mathrm{~Hz}), 4.20$ $(\mathrm{dd}, 1 \mathrm{H}, J=6.9,5.7 \mathrm{~Hz}), 3.99(\mathrm{td}, 1 \mathrm{H}, J=8.5,3.6 \mathrm{~Hz}), 3.77$ $(\mathrm{s}, 3 \mathrm{H}), 3.66-3.75(\mathrm{~m}, 2 \mathrm{H}), 3.35(\mathrm{dd}, 1 \mathrm{H}, J=9.3,8.2 \mathrm{~Hz})$, $1.43(\mathrm{~s}, 3 \mathrm{H}), 1.31(\mathrm{~s}, 3 \mathrm{H}) .{ }^{13} \mathrm{C} \mathrm{NMR}\left(101 \mathrm{MHz}, \mathrm{CD}_{3} \mathrm{COCD}_{3}\right)$ $\delta 160.04,140.20,140.13,132.34,130.24,128.99,128.92$, $128.55,128.43,128.13,128.06,114.25,109.89,83.30,80.08$, $78.86,74.85,74.77,74.06,73.17,73.06,72.81,55.49,28.12$, 26.04 .

PMB Removal Model Reaction: DL-1,4-Di-O-Benzyl-2,3-Oisopropylidene-myo-inositol (33). To a solution of 45 (60 $\mathrm{mg}, 0.115 \mathrm{mmol})$ in anhydrous DCM $(5 \mathrm{~mL})$ was added a solution of TFA $(0.5 \mathrm{~mL})$ in anhydrous DCM $(0.5 \mathrm{~mL})$. After stirring at room temperature for $4 \mathrm{~min}$, the reaction was quenched with $\mathrm{Et}_{3} \mathrm{~N}(1 \mathrm{~mL})$ and concentrated to dryness in vacuum. DCM $(20 \mathrm{~mL})$ was added to the residue and stirred for $5 \mathrm{~min}$. The mixture was then filtered and rinsed with DCM $(2 \times 5 \mathrm{~mL})$. The filtrate was evaporated and subjected to flash chromatography and eluted with a gradient solvent of DCM to 70\% EtOAc/DCM. Compound 33 was obtained as a white solid $(37 \mathrm{mg}, 80 \%)$. mp $158-158^{\circ} \mathrm{C}$ (lit $\left.{ }^{96} 160-161{ }^{\circ} \mathrm{C}\right) .{ }^{1} \mathrm{H}$ NMR was identical to the standard sample.

3'-O-(2"-O-Benzyl-5", 6"-O-isopropylidene)-1" -D-chiro-inosityl]-5'-O-benzyl Adenosine (42). To a solution of 41 (45 $\mathrm{mg}, 0.058 \mathrm{mmol})$ in anhydrous DCM $(0.5 \mathrm{~mL})$ was added a solution of TFA $(114 \mathrm{mg}, 1 \mathrm{mmol})$ in anhydrous DCM $(0.5$ $\mathrm{mL})$. After stirring at room temperature for $4 \mathrm{~min}$, the reaction mixture was quenched with $\mathrm{NH}_{3}-\mathrm{CH}_{3} \mathrm{OH}(7 \mathrm{~N}, 2 \mathrm{~mL})$ and concentrated to dryness in vacuo. DCM $(20 \mathrm{~mL})$ was added to the residue, and the mixture stirred for $5 \mathrm{~min}$. The mixture was then filtered and solid residue rinsed with DCM $(2 \times 5 \mathrm{~mL})$. The filtrate was evaporated and subjected to flash chromatography and eluted with a solvent gradient of DCM to $10 \%$ $\mathrm{MeOH} / \mathrm{DCM}$. Compound $\mathbf{4 2}$ was obtained as a clear oil (24 $\mathrm{mg}, 63 \%) .{ }^{1} \mathrm{H} \mathrm{NMR}\left(400 \mathrm{MHz}, \mathrm{CD}_{3} \mathrm{COCD}_{3}\right) \delta 8.21(\mathrm{~s}, 1 \mathrm{H})$, $8.21(\mathrm{~s}, 1 \mathrm{H}), 7.21-7.46(\mathrm{~m}, 10 \mathrm{H}), 6.66\left(\mathrm{~s}, 2 \mathrm{H}, \mathrm{NH}_{2}\right), 6.05(\mathrm{~d}$, $1 \mathrm{H}, J=3.6 \mathrm{~Hz}), 4.89(\mathrm{~d}, 1 \mathrm{H}, J=11.8 \mathrm{~Hz}), 4.81(\mathrm{~d}, 1 \mathrm{H}, J=$ $11.8 \mathrm{~Hz}), 4.76(\mathrm{t}, 1 \mathrm{H}, J=4.1 \mathrm{~Hz}), 4.69(\mathrm{dd}, 1 \mathrm{H}, J=6.0,4.9$ $\mathrm{Hz}), 4.64(\mathrm{~d}, 1 \mathrm{H}, J=12.0 \mathrm{~Hz}), 4.60(\mathrm{~d}, 1 \mathrm{H}, J=12.0 \mathrm{~Hz}), 4.36$ $(\mathrm{dd}, 1 \mathrm{H}, J=5.7,3.7 \mathrm{~Hz}), 4.27(\mathrm{dt}, 1 \mathrm{H}, J=5.7,3.5 \mathrm{~Hz}), 4.21(\mathrm{t}$, $1 \mathrm{H}, J=3.3 \mathrm{~Hz}), 4.10(\mathrm{dd}, 1 \mathrm{H}, J=7.6,5.7 \mathrm{~Hz}), 3.90(\mathrm{t}, 1 \mathrm{H}, J=$ $8.6 \mathrm{~Hz}), 3.85(\mathrm{dd}, 1 \mathrm{H}, J=10.8,3.3 \mathrm{~Hz}), 3.77(\mathrm{dd}, 1 \mathrm{H}, J=$ $10.9,3.8 \mathrm{~Hz}$ ), $3.70(\mathrm{dd}, 1 \mathrm{H}, J=8.4,3.0 \mathrm{~Hz}), 3.56(\mathrm{dd}, 1 \mathrm{H}, J=$ 8.9, $7.5 \mathrm{~Hz}), 1.39$ (s, 3H), $1.27(\mathrm{~s}, 3 \mathrm{H}) .{ }^{13} \mathrm{C}$ NMR (101 MHz, $\left.\mathrm{CD}_{3} \mathrm{COCD}_{3}\right) \delta 157.14,157.0,153.82,150.69,140.01,139.34$, 139.12, 129.28, 129.17, 129.00, 128.55, 128.49, 128.48, 109.94, $89.45,82.34,80.23,80.22,80.00,78.29,77.14,76.32,74.53$, $74.47,73.98,73.22,70.21,28.40,26.30$. HRMS-ESI $(\mathrm{m} / z)$ required for $[\mathrm{M}+\mathrm{H}]^{+} \mathrm{C}_{33} \mathrm{H}_{40} \mathrm{~N}_{5} \mathrm{O}_{9} 650.2815$, found 650.2816.

5'-O-Benzyl-2'-O-dibenzylphosphoryl-6-N-dibenzylphosphoryl-3'-O-(2"-O-benzyl-3", 4" -dibenzylphosphoryl-5", 6" O-isopropylidene-1" -D-chiro-inosityl)adenosine (43) and $5^{\prime}$ O-Benzyl-2'-O-dibenzylphosphoryl-3'-O-(2"-O-benzyl-3", 4" dibenzylphosphoryl-5", 6"-O-isopropylidene-1" -D-chiroinosityl)adenosine (44). The mixture of imidazolium triflate (44 $\mathrm{mg}, 0.2 \mathrm{mmol}$ ) and bis(benzyloxy)diisopropylaminophosphine $(66 \mathrm{mg}, 0.19 \mathrm{mmol})$ in DCM $(0.75 \mathrm{~mL})$ and $\mathrm{CD}_{2} \mathrm{Cl}_{2}(0.75 \mathrm{~mL})$ was stirred under argon at room 
temperature. After $20 \mathrm{~min}$, the solution was added to a flask containing compound $42(24 \mathrm{mg}, 0.037 \mathrm{mmol})$. The mixture was stirred for another $1 \mathrm{~h}$ under the same conditions. ${ }^{31} \mathrm{P}$ NMR spectroscopy indicated reaction completeness. The reaction was quenched by adding a drop of water and cooled to $-78{ }^{\circ} \mathrm{C}$. tert-Butyl hydroperoxide $(0.3 \mathrm{~mL}, 70 \%$ water solution) was added, and the mixture was brought to room temperature. After stirring for $30 \mathrm{~min}$, the reaction was quenched by adding $\mathrm{Na}_{2} \mathrm{SO}_{3}$ ( $5 \mathrm{~mL}, 10 \%$ water solution), followed by DCM $(60 \mathrm{~mL})$. After separation, the organic phase was washed with brine, dried over $\mathrm{Na}_{2} \mathrm{SO}_{4}$, and concentrated in vacuo to give a clear oil. The crude product was subjected to flash chromatography and eluted with a solvent gradient of DCM to $7 \% \mathrm{MeOH} / \mathrm{DCM}$. Compound 43 was obtained as a clear oil $(25 \mathrm{mg}, 40 \%)$. $[\alpha]_{\mathrm{D}}{ }^{23}=-5.5^{\circ}\left(c=0.22, \mathrm{CH}_{3} \mathrm{CN}\right) .{ }^{1} \mathrm{H}$ NMR (400 MHz, CD $\left.\mathrm{COCD}_{3}\right): \delta 8.67(\mathrm{br}, 1 \mathrm{H}, \mathrm{NH}), 8.49(\mathrm{~s}$, $1 \mathrm{H}), 8.40(\mathrm{~s}, 1 \mathrm{H}), 7.18-7.44(\mathrm{~m}, 50 \mathrm{H}), 6.39(\mathrm{~d}, 1 \mathrm{H}, J=4.6$ $\mathrm{Hz}), 5.62(\mathrm{dt}, 1 \mathrm{H}, J=8.0,4.7 \mathrm{~Hz}), 5.22-5.32(\mathrm{~m}, 4 \mathrm{H}), 5.06-$ $5.19(\mathrm{~m}, 8 \mathrm{H}), 4.99(\mathrm{dd}, 2 \mathrm{H}, J=8.7,1.9 \mathrm{~Hz}), 4.92(\mathrm{dd}, 2 \mathrm{H}, J=$ 8.3, $2.4 \mathrm{~Hz}), 4.83(\mathrm{t}, 1 \mathrm{H}, J=4.7 \mathrm{~Hz}), 4.69-4.76(\mathrm{~m}, 4 \mathrm{H})$, 4.60-4.67 (m, 3H), $4.51(\mathrm{dd}, 1 \mathrm{H}, J=9.4,7.1 \mathrm{~Hz}), 4.46(\mathrm{dd}$, $1 \mathrm{H}, J=4.9,2.7 \mathrm{~Hz}), 4.44(\mathrm{~d}, 1 \mathrm{H}, J=1.8 \mathrm{~Hz}), 4.22(\mathrm{dd}, 1 \mathrm{H}, J=$ 6.7, $2.1 \mathrm{~Hz}), 3.89$ (dd, $1 \mathrm{H}, J=10.9,2.7 \mathrm{~Hz}), 3.82(\mathrm{dd}, 1 \mathrm{H}, J=$ 11.0, $3.3 \mathrm{~Hz}), 1.41$ (s, 3H), 1.25 (s, 3H). ${ }^{31} \mathrm{P}$ NMR (162 MHz, ${ }^{1} \mathrm{H}$-decoupled, $\left.\mathrm{CD}_{3} \mathrm{COCD}_{3}\right): \delta-0.90,-1.17,-1.50,-1.50$. HRMS-ESI $(m / z)$ required for $[\mathrm{M}+\mathrm{H}]^{+} \mathrm{C}_{89} \mathrm{H}_{92} \mathrm{~N}_{5} \mathrm{O}_{21} \mathrm{P}_{4}$ 1690.5225, found 1690.5187. Compound 44 was obtained as a glassy residue $(17 \mathrm{mg}, 32 \%) .[\alpha]_{\mathrm{D}}{ }^{23}=-10.0^{\circ}(c=0.15$; $\mathrm{CH}_{3} \mathrm{CN}$ ). ${ }^{1} \mathrm{H}$ NMR (400 MHz, $\left.\mathrm{CD}_{3} \mathrm{COCD}_{3}\right): \delta 8.20(\mathrm{~s}, 1 \mathrm{H})$, 8.17 (s, 1H,), 7.19-7.44 (m, 40H), 6.65 (br, 2H, $\left.\mathrm{NH}_{2}\right), 6.39$ $(\mathrm{d}, 1 \mathrm{H}, J=4.3 \mathrm{~Hz}), 5.60(\mathrm{dt}, 1 \mathrm{H}, J=7.9,4.7 \mathrm{~Hz}), 5.04-5.22$ (m, $8 \mathrm{H}), 4.99(\mathrm{~s}, 1 \mathrm{H}), 4.97(\mathrm{~s}, 1 \mathrm{H}), 4.91(\mathrm{~d}, 1 \mathrm{H}, \mathrm{J}=2.4 \mathrm{~Hz})$, $4.89(\mathrm{~d}, 1 \mathrm{H}, J=2.0 \mathrm{~Hz}), 4.81(\mathrm{t}, 1 \mathrm{H}, J=4.7 \mathrm{~Hz}), 4.63-4.75$ $(\mathrm{m}, 7 \mathrm{H}), 4.51(\mathrm{dd}, 1 \mathrm{H}, J=9.4,7.1 \mathrm{~Hz}), 4.44(\mathrm{dt}, 2 \mathrm{H}, J=6.5$, $2.3 \mathrm{~Hz}$ ), $4.22(\mathrm{dd}, 1 \mathrm{H}, J=6.8,2.1 \mathrm{~Hz}), 3.88(\mathrm{dd}, 1 \mathrm{H}, J=10.9$, $2.8 \mathrm{~Hz}$ ), $3.81(\mathrm{dd}, 1 \mathrm{H}, J=10.9,3.3 \mathrm{~Hz}), 1.42(\mathrm{~s}, 3 \mathrm{H}), 1.26(\mathrm{~s}$, $3 \mathrm{H}) .{ }^{31} \mathrm{P}$ NMR (162 MHz, ${ }^{1} \mathrm{H}$-decoupled, $\left.\mathrm{CD}_{3} \mathrm{COCD}_{3}\right): \delta$ $-1.26,-1.51,-1.53$. HRMS-ESI $(m / z)$ required for $[\mathrm{M}+\mathrm{H}]^{+}$ $\mathrm{C}_{75} \mathrm{H}_{79} \mathrm{~N}_{5} \mathrm{O}_{18} \mathrm{P}_{3}$ 1430.4622, found 1430.4594 .

3'-O-(1"-D-chiro-Inosityl)adenosine 2',3", 4" -trisphosphate (D-Chiro-Inositol adenophostin) (5). To a solution of $43(23 \mathrm{mg}, 0.013 \mathrm{mmol})$ in methanol-water $(4-0.5 \mathrm{~mL})$ was added cyclohexene $(1 \mathrm{~mL})$, followed by $\mathrm{Pd}(\mathrm{OH})_{2}(80 \mathrm{mg}$, $20 \% \mathrm{Pd}$ on charcoal, $50 \%$ water). The mixture was refluxed for $18 \mathrm{~h}$, cooled to room temperature, and filtered through a syringe membrane filter (Whatman, PTEF-S, $0.2 \mu \mathrm{m}$ ). The filter was washed repeatedly with methanol-water. The filtrate was evaporated in vacuo at $35^{\circ} \mathrm{C}$ to give a clear residue $(8 \mathrm{mg}$, $78 \%$ ). The product was subjected to purification on a semiprep HPLC system. Appropriate fractions identified by analytical HPLC were collected, evaporated in vacuo, and then coevaporated with water $(\times 2)$ to give the title compound in TEAB salt form as a colorless glass $(4.8 \mu \mathrm{mol}$ by UV quantification at the max wavelength of $259 \mathrm{~nm}, 37 \%$ yield for deprotection and purification). ${ }^{1} \mathrm{H}$ NMR (500 MHz, MeOD) $\delta 8.34(\mathrm{~s}, 1 \mathrm{H}), 8.18(\mathrm{~s}, 1 \mathrm{H}), 6.21(\mathrm{~d}, 1 \mathrm{H}, J=6.3 \mathrm{~Hz}), 5.31(\mathrm{dt}$, $1 \mathrm{H}, J=7.7,5.5 \mathrm{~Hz}), 4.61(\mathrm{q}, 2 \mathrm{H}, J=9.6 \mathrm{~Hz}), 4.28(\mathrm{q}, 1 \mathrm{H}, J=$ $9.0 \mathrm{~Hz}), 4.23(\mathrm{q}, 1 \mathrm{H}, J=3.0 \mathrm{~Hz}), 3.92-4.11(\mathrm{~m}, 4 \mathrm{H}), 3.86$ $(\mathrm{dd}, 1 \mathrm{H}, J=12.4,3.0 \mathrm{~Hz}), 3.75(\mathrm{dd}, 1 \mathrm{H}, J=12.5,3.1 \mathrm{~Hz}) .{ }^{13} \mathrm{C}$ NMR (126 MHz, MeOD) $\delta 157.45,153.55,150.52,142.14$, 120.83, 89.63, 86.78, 81.40, 80.93, 78.64, 78.12, 76.80, 73.08, 72.88, 71.82, 63.52. ${ }^{31} \mathrm{P}$ NMR (202 $\mathrm{MHz},{ }^{1} \mathrm{H}$-decoupled, $\mathrm{MeOD}): \delta 2.75$ (s), $1.54(\mathrm{~s}), 0.54(\mathrm{~s}) .{ }^{31} \mathrm{P}$ NMR $(202 \mathrm{MHz}$,
${ }^{1} \mathrm{H}$-coupled, MeOD) $\delta 2.76(\mathrm{~d}, J=8.8 \mathrm{~Hz}), 1.54(\mathrm{~d}, J=8.9$ $\mathrm{Hz}), 0.54(\mathrm{~d}, J=7.9 \mathrm{~Hz})$. HRMS-ESI $(\mathrm{m} / z)$ required for $[\mathrm{M}-$ $\mathrm{H}]^{-} \mathrm{C}_{16} \mathrm{H}_{25} \mathrm{~N}_{5} \mathrm{O}_{18} \mathrm{P}_{3}$ 668.0413, found 668.0415; UV $\left(\mathrm{H}_{2} \mathrm{O}\right.$, $\mathrm{pH}$ $7), \lambda_{\max } 259 \mathrm{~nm}(\varepsilon 15400)$.

\section{ASSOCIATED CONTENT}

\section{SI Supporting Information}

The Supporting Information is available free of charge at https://pubs.acs.org/doi/10.1021/acsomega.0c04145.

${ }^{1} \mathrm{H},{ }^{13} \mathrm{C}$, and ${ }^{31} \mathrm{P}$ NMR spectra for all novel compounds and intermediates; high-resolution MS; and HPLC data (PDF)

\section{AUTHOR INFORMATION}

\section{Corresponding Author}

Barry V. L. Potter - Medicinal Chemistry \& Drug Discovery, Department of Pharmacology, University of Oxford, Oxford OX1 3QT, U.K.; 1 orcid.org/0000-0003-3255-9135; Phone: +44-1865-271945; Email: barry.potter@ pharm.ox.ac.uk; Fax: +44-1865-271853

\section{Authors}

Xiangdong Su - Medicinal Chemistry \& Drug Discovery, Department of Pharmacology, University of Oxford, Oxford OX1 3QT, U.K.

Wolfgang Dohle - Medicinal Chemistry \& Drug Discovery, Department of Pharmacology, University of Oxford, Oxford OX1 3QT, U.K.

Stephen J. Mills - Medicinal Chemistry \& Drug Discovery, Department of Pharmacology, University of Oxford, Oxford OX1 3QT, U.K.

Joanna M. Watt - Medicinal Chemistry \& Drug Discovery, Department of Pharmacology, University of Oxford, Oxford OX1 3QT, U.K.; Wolfson Laboratory of Medicinal Chemistry, Department of Pharmacy and Pharmacology, University of Bath, Bath BA2 7AY, U.K.; (1) orcid.org/0000-0003-28546622

Ana M. Rossi - Department of Pharmacology, University of Cambridge, Cambridge CB2 1PD, U.K.

Colin W. Taylor - Department of Pharmacology, University of Cambridge, Cambridge CB2 1PD, U.K.; 이이.org/00000001-7771-1044

Complete contact information is available at:

https://pubs.acs.org/10.1021/acsomega.0c04145

\section{Author Contributions}

X.S., W.D., and S.J.M. contributed equally to this work. B.V.L.P. conceived and designed the overall study with focused chemical strategies elaborated by X.S., W.D., and S.J.M. X.S. and W.D. synthesized and characterized all compounds. J.M.W. purified and characterized the final compound. A.M.R. performed $\mathrm{Ca}^{2+}$ flux and binding assays with C.W.T. X.S. and B.V.L.P. wrote the manuscript with input from all authors.

\section{Notes}

The authors declare no competing financial interest. All data generated or analyzed during this study are included in this published article and its Supporting Information files.

\section{ACKNOWLEDGMENTS}

This work was supported by the Wellcome Trust. BVLP and CWT are Wellcome Trust Senior Investigators (grant nos. 
101010 and 101844, respectively). A.M.R. is a Fellow at Queens' College, Cambridge. We thank Dr. A. M. Riley for highly constructive discussions during this work.

\section{ABBREVIATIONS}

$\mathrm{IP}_{3} \mathrm{R}$, D-myo-inositol 1,4,5-trisphosphate receptor; $\mathrm{IP}_{3}$, D-myoinositol 1,4,5-trisphosphate; AdA, glyconucleotide adenophostin A; InsAdA, D-chiro-inositol adenophostin; ER, endoplasmic reticulum; IBC, $\mathrm{IP}_{3}$-binding core; $\mathrm{PMB}, p$-methoxybenzyl; $\mathrm{SAR}$, structure-activity relationship; DMF, $N, N$-dimethylformamide; CAN, ceric ammonium nitrate; GPI, glycosylphosphatidylinositol; TBAI, tetrabutylammonium iodide; DDQ 2,3-dichloro-5,6-dicyano-p-benzoquinone; TMSOTf, trimethylsilyl trifluoromethanesulfonate; $p$ TSA, toluene-4-sulfonic acid

\section{REFERENCES}

(1) Rossi, A. M.; Taylor, C. W. $\mathrm{IP}_{3}$ receptors - lessons from analyses ex cellula. J. Cell Sci. 2018, 132, No. jcs222463.

(2) Alzayady, K. J.; Wang, L.; Chandrasekhar, R.; Wagner, L. E., 2nd; Van Petegem, F.; Yule, D. I. Defining the stoichiometry of inositol 1,4,5-trisphosphate binding required to initiate $\mathrm{Ca}^{2+}$ release. Sci. Signaling 2016, 9, No. ra35.

(3) Bosanac, I.; Alattia, J.-R.; Mal, T. K.; Chan, J.; Talarico, S.; Tong, F. K.; Tong, K. I.; Yoshikawa, F.; Furuichi, T.; Iwai, M.; Michikawa, T.; Mikoshiba, K.; Ikura, M. Structure of the inositol 1,4,5trisphosphate receptor binding core in complex with its ligand. Nature 2002, 420, 696.

(4) Potter, B. V. L.; Lampe, D. Chemistry of Inositol Lipid Mediated Cellular Signaling. Angew. Chem., Int. Ed. 1995, 34, 1933-1972.

(5) Sureshan, K. M.; Riley, A. M.; Thomas, M. P.; Tovey, S. C.; Taylor, C. W.; Potter, B. V. L. Contribution of Phosphates and Adenine to the Potency of Adenophostins at the $\mathrm{IP}_{3}$ Receptor: Synthesis of All Possible Bisphosphates of Adenophostin A. J. Med. Chem. 2012, 55, 1706-1720.

(6) Lin, C.-C.; Baek, K.; Lu, Z. Apo and InsP-bound crystal structures of the ligand-binding domain of an $\mathrm{InsP}_{3}$ receptor. Nat. Struct. Mol. Biol. 2011, 18, 1172-1174.

(7) Seo, M.-D.; Velamakanni, S.; Ishiyama, N.; Stathopulos, P. B.; Rossi, A. M.; Khan, S. A.; Dale, P.; Li, C.; Ames, J. B.; Ikura, M.; Taylor, C. W. Structural and functional conservation of key domains in InsP $\mathrm{P}_{3}$ and ryanodine receptors. Nature 2012, 483, 108.

(8) Paknejad, N.; Hite, R. K. Structural basis for the regulation of inositol trisphosphate receptors by $\mathrm{Ca}^{2+}$ and $\mathrm{IP}_{3}$. Nat. Struct. Mol. Biol. 2018, 25, 660-668.

(9) Konieczny, V.; Stefanakis, J. G.; Sitsanidis, E. D.; Ioannidou, N.A. T.; Papadopoulos, N. V.; Fylaktakidou, K. C.; Taylor, C. W.; Koumbis, A. E. Synthesis of inositol phosphate-based competitive antagonists of inositol 1,4,5-trisphosphate receptors. Org. Biomol. Chem. 2016, 14, 2504-2514.

(10) Saleem, H.; Tovey, S. C.; Rahman, T.; Riley, A. M.; Potter, B. V. L.; Taylor, C. W. Stimulation of Inositol 1,4,5-Trisphosphate $\left(\mathrm{IP}_{3}\right)$ Receptor Subtypes by Analogues of $\mathrm{IP}_{3}$. PLoS One 2013, 8, No. e54877.

(11) Wilcox, R. A.; Primrose, W. U.; Nahorski, S. R.; Challiss, R. A. $\mathrm{J}$. New developments in the molecular pharmacology of the myoinositol 1,4,5-trisphosphate receptor. Trends Pharmacol. Sci. 1998, 19, $467-475$.

(12) Vasudevan, S. R.; Singh, N.; Churchill, G. C. Scaffold Hopping with Virtual Screening from $\mathrm{IP}_{3}$ to a Drug-Like Partial Agonist of the Inositol Trisphosphate Receptor. ChemBioChem 2014, 15, 27742782.

(13) Takahashi, M.; Kagasaki, T.; Hosoya, T.; Takahashi, S. Adenophostins A and B: potent agonists of inositol-1,4,5-trisphosphate receptor produced by Penicillium brevicompactum. Taxonomy, fermentation, isolation, physico-chemical and biological properties. J. Antibiot. 1993, 46, 1643-1647.
(14) Rossi, A. M.; Riley, A. M.; Potter, B. V. L.; Taylor, C. Adenophostins: High-Affinity Agonists of $\mathrm{IP}_{3}$ Receptors. In Structure and Function of Calcium Release Channels; Serysheva, I. I., Ed.; Current Topics in Membranes; Elsevier, 2010; Vol. 66, pp 209-233.

(15) Rosenberg, H. J.; Riley, A. M.; Laude, A. J.; Taylor, C. W.; Potter, B. V. L. Synthesis and $\mathrm{Ca}^{2+}$-Mobilizing Activity of PurineModified Mimics of Adenophostin A: A Model for the Adenophostin-Ins $(1,4,5) \mathrm{P}_{3}$ Receptor Interaction. J. Med. Chem. 2003, 46, 4860-4871.

(16) Fan, G.; Baker, M. R.; Wang, Z.; Seryshev, A. B.; Ludtke, S. J.; Baker, M. L.; Serysheva, I. I. Cryo-EM reveals ligand induced allostery underlying $\mathrm{InsP}_{3} \mathrm{R}$ channel gating. Cell Res. 2018, 28, 1158-1170.

(17) Rossi, A. M.; Sureshan, K. M.; Riley, A. M.; Potter, B. V. L.; Taylor, C. W. Selective determinants of inositol 1,4,5-trisphosphate and adenophostin A interactions with type 1 inositol 1,4,5trisphosphate receptors. Br. J. Pharmacol. 2010, 161, 1070-1085.

(18) Sureshan, K. M.; Riley, A. M.; Rossi, A. M.; Tovey, S. C.; Dedos, S. G.; Taylor, C. W.; Potter, B. V. L. Activation of $\mathrm{IP}_{3}$ receptors by synthetic bisphosphate ligands. Chem. Commun. 2009, 1204-1206.

(19) Riley, A. M.; Correa, V.; Mahon, M. F.; Taylor, C. W.; Potter, B. V. L. Bicyclic Analogues of D-myo-Inositol 1,4,5-Trisphosphate Related to Adenophostin A: Synthesis and Biological Activity. J. Med. Chem. 2001, 44, 2108-2117.

(20) Correa, V.; Riley, A. M.; Shuto, S.; Horne, G.; Nerou, E. P.; Marwood, R. D.; Potter, B. V. L.; Taylor, C. W. Structural Determinants of Adenophostin A Activity at Inositol Trisphosphate Receptors. Mol. Pharmacol. 2001, 59, 1206.

(21) Mochizuki, T.; Kondo, Y.; Abe, H.; Tovey, S. C.; Dedos, S. G.; Taylor, C. W.; Paul, M.; Potter, B. V. L.; Matsuda, A.; Shuto, S. Synthesis of Adenophostin A Analogues Conjugating an Aromatic Group at the $5^{\prime}$-Position as Potent $\mathrm{IP}_{3}$ Receptor Ligands. J. Med. Chem. 2006, 49, 5750-5758.

(22) Oura, T.; Murata, K.; Morita, T.; Nezu, A.; Arisawa, M.; Shuto, S.; Tanimura, A. Highly Sensitive Measurement of Inositol 1,4,5Trisphosphate by Using a New Fluorescent Ligand and Ligand Binding Domain Combination. ChemBioChem 2016, 17, 1509-1512.

(23) Jenkins, D. J.; Potter, B. V. L. A Ca ${ }^{2+}$-mobilising carbohydratebased polyphosphate: Synthesis of 2-hydroxyethyl $\alpha$-D-glucopyranoside 2',3,4-trisphosphate. Carbohydr. Res. 1996, 287, 169-182.

(24) Wilcox, R. A.; Erneux, C.; Primrose, W. U.; Gigg, R.; Nahorski, S. R. 2-Hydroxyethyl-alpha-D-Glucopyranoside-2,3' $4^{\prime}$-Trisphosphate, a Novel, Metabolically Resistant, Adenophostin A and myo-Inositol1,4,5-Trisphosphate Analog, Potently Interacts with the myo-Inositol1,4,5-Trisphosphate Receptor. Mol. Pharmacol. 1995, 47, 1204-1211.

(25) Beecroft, M. D.; Marchant, J. S.; Riley, A. M.; Van Straten, N. C. R.; Van der Marel, G. A.; Van Boom, J. H.; Potter, B. V. L.; Taylor, C. W. Acyclophostin: A Ribose-Modified Analog of Adenophostin A with High Affinity for Inositol 1,4,5-Trisphosphate Receptors and $\mathrm{pH}$ Dependent Efficacy. Mol. Pharmacol. 1999, 55, 109.

(26) Shipton, M. L.; Riley, A. M.; Rossi, A. M.; Brearley, C. A.; Taylor, C. W.; Potter, B. V. L. Both D- and L-Glucose Polyphosphates Mimic D-myo-Inositol 1,4,5-Trisphosphate: New Synthetic Agonists and Partial Agonists at the Ins $(1,4,5) \mathrm{P}_{3}$ Receptor. J. Med. Chem. 2020, $63,5442-5457$.

(27) Marchant, J. S.; Beecroft, M. D.; Riley, A. M.; Jenkins, D. J.; Marwood, R. D.; Taylor, C. W.; Potter, B. V. L. Disaccharide Polyphosphates Based upon Adenophostin A Activate Hepatic D-myoInositol 1,4,5-Trisphosphate Receptors. Biochemistry 1997, 36, 12780-12790.

(28) Marwood, R. D.; Riley, A. M.; Correa, V.; Taylor, C. W.; Potter, B. V. L. Simplification of adenophostin A defines a minimal structure for potent glucopyranoside-based mimics of D-myo-inositol 1,4,5trisphosphate. Bioorg. Med. Chem. Lett. 1999, 9, 453-458.

(29) Marwood, R. D.; Jenkins, D. J.; Correa, V.; Taylor, C. W.; Potter, B. V. L. Contribution of the Adenine Base to the Activity of Adenophostin A Investigated Using a Base Replacement Strategy. J. Med. Chem. 2000, 43, 4278-4287. 
(30) Sureshan, K. M.; Trusselle, M.; Tovey, S. C.; Taylor, C. W.; Potter, B. V. L. Guanophostin A: Synthesis and evaluation of a high affinity agonist of the D-myo-inositol 1,4,5-trisphosphate receptor. Chem. Commun. 2006, 2015-2017.

(31) Mochizuki, T.; Tanimura, A.; Nezu, A.; Ito, M.; Abe, H.; Ito, Y.; Arisawa, M.; Shuto, S. Design and synthesis of indole derivatives of adenophostin A. A entry into subtype-selective $\mathrm{IP}_{3}$ receptor ligands. Tetrahedron Lett. 2010, 51, 977-979.

(32) Vibhute, A. M.; Konieczny, V.; Taylor, C. W.; Sureshan, K. M. Triazolophostins: a library of novel and potent agonists of $\mathrm{IP}_{3}$ receptors. Org. Biomol. Chem. 2015, 13, 6698-6710.

(33) Vibhute, A. M.; Pushpanandan, P.; Varghese, M.; Koniecnzy, V.; Taylor, C. W.; Sureshan, K. M. Synthesis of dimeric analogs of adenophostin A that potently evoke $\mathrm{Ca}^{2+}$ release through $\mathrm{IP}_{3}$ receptors. RSC Adv. 2016, 6, 86346-86351.

(34) Sureshan, K. M.; Trusselle, M.; Tovey, S. C.; Taylor, C. W.; Potter, B. V. L. 2-Position Base-Modified Analogues of Adenophostin A as High-Affinity Agonists of the D-myo-Inositol Trisphosphate Receptor: In Vitro Evaluation and Molecular Modeling. J. Org. Chem. 2008, 73, 1682-1692.

(35) Dohle, W.; Su, X.; Mills, S. J.; Rossi, A. M.; Taylor, C. W.; Potter, B. V. L. A synthetic cyclitol-nucleoside conjugate polyphosphate is a highly potent second messenger mimic. Chem. Sci. 2019, 10, 5382-5390.

(36) Mills, S. J.; Rossi, A. M.; Konieczny, V.; Bakowski, D.; Taylor, C. W.; Potter, B. V. L. D-chiro-Inositol Ribophostin: A Highly Potent Agonist of D-myo-Inositol 1,4,5-Trisphosphate Receptors: Synthesis and Biological Activities. J. Med. Chem. 2020, 63, 3238-3251.

(37) Kılbaș, B.; Balci, M. Recent advances in inositol chemistry: synthesis and applications. Tetrahedron 2011, 67, 2355-2389.

(38) Devaraj, S.; Jagdhane, R. C.; Shashidhar, M. S. Relative reactivity of hydroxyl groups in inositol derivatives: role of metal ion chelation. Carbohydr. Res. 2009, 344, 1159-1166.

(39) Sureshan, K. M.; Shashidhar, M. S.; Praveen, T.; Das, T. Regioselective Protection and Deprotection of Inositol Hydroxyl Groups. Chem. Rev. 2003, 103, 4477-4504.

(40) Gigg, J.; Gigg, R.; Payne, S.; Conant, R. ( \pm )-1,2:4,5-Di-Oisopropylidene-myo-inositol. Carbohydr. Res. 1985, 142, 132-134.

(41) Khersonsky, S. M.; Chang, Y.-T. ( \pm )-1,2:5,6-Di-O-isopropylidene-myo-inositol and ( \pm )-6-O-benzoyl-1,2:4,5-di-O-isopropylidenemyo-inositol: a practical preparation of key intermediates for myoinositol phosphates. Carbohydr. Res. 2002, 337, 75-78.

(42) Sridhar, M.; Kumar, B. A.; Narender, R. Expedient and simple method for regeneration of alcohols from toluenesulfonates using $\mathrm{Mg}$ $\mathrm{MeOH}$. Tetrahedron Lett. 1998, 39, 2847-2850.

(43) Isono, K. Nucleoside antibiotics: structure, biological activity, and biosynthesis. J. Antibiot. 1988, 41, 1711-1739.

(44) Ogita, T.; Ōtake, N.; Miyazaki, Y.; Yonehara, H.; Macfarlane, R. D.; McNeal, C. J. The structure of adenomycin (C19-97 substance). Tetrahedron Lett. 1980, 21, 3203-3206.

(45) Noguchi, K.; Okuyama, K.; Ohno, S.; Hidano, T.; Wakiuchi, N.; Tarui, T.; Tamaki, H.; Kishihara, S.; Fujii, S. Molecular and crystal structure of galactinol dihydrate [1-O-( $\alpha$-D-galactopyranosyl)-myoinositol dihydrate]. Carbohydr. Res. 2000, 328, 241-248.

(46) Jothivasan, V. K.; Hamilton, C. J. Mycothiol: synthesis, biosynthesis and biological functions of the major low molecular weight thiol in actinomycetes. Nat. Prod. Rep. 2008, 25, 1091-1117.

(47) Paulick, M. G.; Bertozzi, C. R. The Glycosylphosphatidylinositol Anchor: A Complex Membrane-Anchoring Structure for Proteins. Biochemistry 2008, 47, 6991-7000.

(48) Guo, Z. Synthetic Studies of Glycosylphosphatidylinositol (GPI) Anchors and GPI-Anchored Peptides, Glycopeptides, and Proteins. Curr. Org. Synth. 2013, 10, 366-383.

(49) Lee, A. M. M.; Painter, G. F.; Compton, B. J.; Larsen, D. S. Resolution of Orthogonally Protected myo-Inositols with Novozym 435 Providing an Enantioconvergent Pathway to Ac2PIM1. J. Org. Chem. 2014, 79, 10916-10931.

(50) Ohira, S.; Yamaguchi, Y.; Takahashi, T.; Tanaka, H. The chemoselective $\mathrm{O}$-glycosylation of alcohols in the presence of a phosphate diester and its application to the synthesis of oligomannosylated phosphatidyl inositols. Tetrahedron 2015, 71, 6602-6611.

(51) Daniellou, R.; Palmer, D. R. J. Appel-Lee synthesis of glycosyl inositols, substrates for inositol dehydrogenase from Bacillus subtilis. Carbohydr. Res. 2006, 341, 2145-2150.

(52) Koto, S.; Hirooka, M.; Yoshida, T.; Takenaka, K.; Asai, C.; Nagamitsu, T.; Sakuma, H.; Sakurai, M.; Masuzawa, S.; Komiya, M.; Sato, T.; Zen, S.; Yago, K.; Tomonaga, F. Syntheses of Penta-Obenzyl-myo-inositols, $O-\beta$-L-Arabinosyl- $(1 \rightarrow 2)$-sn-myo-inositol, $O-\alpha$-DGalactosyl-( $(1 \rightarrow 3)$-sn-myo-inositol, and $O-\beta$-D-Galactosyl- $(1 \rightarrow 6)-\mathrm{O}-\alpha$ D-galactosyl-(1 $\rightarrow 3)$-sn-myo-inositol. Bull. Chem. Soc. Jpn. 2000, 73, $2521-2529$.

(53) Romeo, G.; Chiacchio, U.; Corsaro, A.; Merino, P. Chemical Synthesis of Heterocyclic-Sugar Nucleoside Analogues. Chem. Rev. 2010, 110, 3337-3370.

(54) Yamaoka, N.; Aso, K.; Matsuda, K. New Syntheses of Nucleosides.1a The Syntheses of Glycopyranosides of Purines, Pyrimidine, and Benzimidazole. J. Org. Chem. 1965, 30, 149-152.

(55) Kazimierczuk, Z.; Cottam, H. B.; Revankar, G. R.; Robins, R. K. Synthesis of $2^{\prime}$-deoxytubercidin, $2^{\prime}$-deoxyadenosine, and related $2^{\prime}$ deoxynucleosides via a novel direct stereospecific sodium salt glycosylation procedure. J. Am. Chem. Soc. 1984, 106, 6379-6382.

(56) Witkowski, J. T.; Robins, R. K.; Sidwell, R. W.; Simon, L. N. Design, synthesis, and broad spectrum antiviral activity of $1-\beta$-Dribofuranosyl-1,2,4-triazole-3-carboxamide and related nucleosides. $J$. Med. Chem. 1972, 15, 1150-1154.

(57) Niedballa, U.; Vorbrueggen, H. Synthesis of nucleosides 17. A general synthesis of $\mathrm{N}$-glycosides. 6 . On the mechanism of the stannic chloride catalyzed silyl Hilbert-Johnson reaction. J. Org. Chem. 1976, 41, 2084-2086.

(58) Nehring, R.; Seeliger, W. A New Synthesis of Polyimides. Angew. Chem., Int. Ed. 1970, 9, 461.

(59) Roy, B.; Depaix, A.; Périgaud, C.; Peyrottes, S. Recent Trends in Nucleotide Synthesis. Chem. Rev. 2016, 116, 7854-7897.

(60) Roberts, C.; Madsen, R.; Fraser-Reid, B. Studies Related to Synthesis of Glycophosphatidylinositol Membrane-Bound Protein Anchors. 5. n-Pentenyl Ortho Esters for Mannan Components. J. Am. Chem. Soc. 1995, 117, 1546-1553.

(61) Allen, J. G.; Fraser-Reid, B. n-Pentenyl Glycosyl Orthoesters as Versatile Intermediates in Oligosaccharide Synthesis. The Proteoglycan Linkage Region 1. J. Am. Chem. Soc. 1999, 121, 468-469.

(62) Fraser-Reid, B.; Ganney, P.; Ramamurty, C. V. S.; Gómez, A. M.; López, J. C. A Reverse Strategy for Synthesis of Nucleosides Based on $n$-Pentenyl Orthoester Donors. Chem. Commun. 2013, 49, 3251-3253.

(63) Malik, S.; Dixit, V. A.; Bharatam, P. V.; Kartha, K. P. R. A simple, mild, and regioselective method for the benzylation of carbohydrate derivatives promoted by silver carbonate. Carbohydr. Res. 2010, 345, 559-564.

(64) Konradsson, P.; Mootoo, D. R.; McDevitt, R. E.; Fraser-Reid, B. Iodonium ion generated in situ from $\mathrm{N}$-iodosuccinimide and trifluoromethanesulphonic acid promotes direct linkage of 'disarmed' pent-4-enyl glycosides. J. Chem. Soc., Chem. Commun. 1990, 270-272.

(65) Oslovsky, V. E.; Drenichev, M. S.; Mikhailov, S. N. Regioselective 1-N-Alkylation and Rearrangement of Adenosine Derivatives. Nucleosides, Nucleotides Nucleic Acids 2015, 34, 475-499.

(66) Siddiqui, N.; Singh, V.; Deshmukh, M. M.; Gurunath, R. Structures, stability and hydrogen bonding in inositol conformers. Phys. Chem. Chem. Phys. 2015, 17, 18514-18523.

(67) Bruce Grindley, T. Applications of Tin-Containing Intermediates to Carbohydrate Chemistry. In Advances in Carbohydrate Chemistry and Biochemistry; Horton, D., Ed.; Academic Press, 1998; Vol. 53, pp 17-142.

(68) Gangadharmath, U. B.; Demchenko, A. V. Nickel(II) ChlorideMediated Regioselective Benzylation and Benzoylation of Diequatorial Vicinal Diols. Synlett 2004, 2191-2193.

(69) Ren, B.; Ramström, O.; Zhang, Q.; Ge, J.; Dong, H. An Iron(III) Catalyst with Unusually Broad Substrate Scope in 
Regioselective Alkylation of Diols and Polyols. Chem. - Eur. J. 2016, 22, 2481-2486.

(70) Dong, H.; Zhou, Y.; Pan, X.; Cui, F.; Liu, W.; Liu, J.; Ramström, O. Stereoelectronic Control in Regioselective Carbohydrate Protection. J. Org. Chem. 2012, 77, 1457-1467.

(71) Lawandi, J.; Rocheleau, S.; Moitessier, N. Regioselective acylation, alkylation, silylation and glycosylation of monosaccharides. Tetrahedron 2016, 72, 6283-6319.

(72) Xu, H.; Zhang, Y.; Dong, H.; Lu, Y.; Pei, Y.; Pei, Z. Organotincatalyzed regioselective benzylation of carbohydrate trans-diols. Tetrahedron Lett. 2017, 58, 4039-4042.

(73) Chen, W.; Deng, Z.; Chen, K.; Dou, D.; Song, F.; Li, L.; Xi, Z. Synthesis and in vitro anticancer activity evaluation of novel bioreversible phosphate inositol derivatives. Eur. J. Med. Chem. 2015, 93, 172-181.

(74) Desai, T.; Gigg, J.; Gigg, R.; Martín-Zamora, E. The preparation of racemic and enantiomerically pure myo-inositol derivatives as intermediates for the synthesis of phosphatidylinositol 3-, 3,4-bis-, and 3,4,5-tris-phosphates and for the synthesis of analogues of 1D-myo-inositol 1,3,4,5-tetrakisphosphate. Carbohydr. Res. 1996, 296, 97-133.

(75) Pedretti, A.; Villa, L.; Vistoli, G. VEGA - An open platform to develop chemo-bio-informatics applications, using plug-in architecture and script programming. J. Comput.-Aided Mol. Des. 2004, 18, $167-173$.

(76) Oikawa, Y.; Yoshioka, T.; Yonemitsu, O. Specific removal of $o$ methoxybenzyl protection by DDQ oxidation. Tetrahedron Lett. 1982, 23, 885-888.

(77) Wright, J. A.; Yu, J.; Spencer, J. B. Sequential removal of the benzyl-type protecting groups $\mathrm{PMB}$ and NAP by oxidative cleavage using CAN and DDQ. Tetrahedron Lett. 2001, 42, 4033-4036.

(78) Yan, L.; Kahne, D. p-Methoxybenzyl Ethers as Acid-Labile Protecting Groups in Oligosaccharide Synthesis. Synlett 1995, 1995, 523-524.

(79) Nifantiev, E. E.; Grachev, M. K.; Burmistrov, S. Y. Amides of Trivalent Phosphorus Acids as Phosphorylating Reagents for ProtonDonating Nucleophiles. Chem. Rev. 2000, 100, 3755-3800.

(80) Beaucage, S. L.; Caruthers, M. H. Deoxynucleoside phosphoramidites-A new class of key intermediates for deoxypolynucleotide synthesis. Tetrahedron Lett. 1981, 22, 1859-1862.

(81) Pon, R. T. Enhanced coupling efficiency using 4-dimethylaminopyridine (DMAP) and either tetrazole, 5-(o-nitrophenyl) tetrazole, or 5-( $p$-nitrophenyl) tetrazole in the solid phase synthesis of oligoribonucleotides by the phosphoramidite procedure. Tetrahedron Lett. 1987, 28, 3643-3646.

(82) Vargeese, C.; Carter, J.; Yegge, J.; Krivjansky, S.; Settle, A.; Kropp, E.; Peterson, K.; Pieken, W. Efficient activation of nucleoside phosphoramidites with 4,5-dicyanoimidazole during oligonucleotide synthesis. Nucleic Acids Res. 1998, 26, 1046-1050.

(83) Hayakawa, Y.; Kataoka, M.; Noyori, R. Benzimidazolium Triflate as an Efficient Promoter for Nucleotide Synthesis via the Phosphoramidite Method. J. Org. Chem. 1996, 61, 7996-7997.

(84) Wei, X. Coupling activators for the oligonucleotide synthesis via phosphoramidite approach. Tetrahedron 2013, 69, 3615-3637.

(85) Gryaznov, S. M.; Letsinger, R. L. Synthesis of oligonucleotides via monomers with unprotected bases. J. Am. Chem. Soc. 1991, 113, 5876-5877.

(86) Hayakawa, Y.; Kataoka, M. Facile Synthesis of Oligodeoxyribonucleotides via the Phosphoramidite Method without Nucleoside Base Protection. J. Am. Chem. Soc. 1998, 120, 12395-12401.

(87) Kuliszewska, E.; Hammerschmidt, F. On the rearrangement of $\mathrm{N}$-aryl- $\mathrm{N}$-Boc-phosphoramidates to $\mathrm{N}$-Boc-protected $o$-aminoarylphosphonates. Monatsh. Chem. 2018, 149, 87-98.

(88) $\mathrm{Hu}, \mathrm{X}$. E. Lewis acid promoted regio- and stereoselective hetero nucleophilic addition to a piperidinyl aziridine. Synthesis of trans 3amino-4-substituted piperidines. Tetrahedron Lett. 2002, 43, 53155318.
(89) Chen, C.-A.; Fang, J.-M. Synthesis of oseltamivir and tamiphosphor from $\mathrm{N}$-acetyl-D-glucosamine. Org. Biomol. Chem. 2013, 11, 7687-7699.

(90) Lönnberg, T.; Ora, M.; Lönnberg, H. Hydrolytic Reactions of Nucleoside Phosphoramidates: Kinetics and Mechanisms. Mini-Rev. Org. Chem. 2010, 7, 33-43.

(91) Koizumi, T.; Haake, P. Acid-catalyzed and alkaline hydrolyses of phosphinamides. Lability of phosphorus-nitrogen bonds in acid and the mechanisms of reaction. J. Am. Chem. Soc. 1973, 95, 8073-8079.

(92) Choy, C. J.; Geruntho, J. J.; Davis, A. L.; Berkman, C. E. Tunable pH-Sensitive Linker for Controlled Release. Bioconjugate Chem. 2016, 27, 824-830.

(93) Hayakawa, Y. Toward an Ideal Synthesis of Oligonucleotides: Development of a Novel Phosphoramidite Method with High Capability. Bull. Chem. Soc. Jpn. 2001, 74, 1547-1565.

(94) Rossi, A. M.; Riley, A. M.; Tovey, S. C.; Rahman, T.; Dellis, O.; Taylor, E. J. A.; Veresov, V. G.; Potter, B. V. L.; Taylor, C. W. Synthetic partial agonists reveal key steps in $\mathrm{IP}_{3}$ receptor activation. Nat. Chem. Biol. 2009, 5, 631.

(95) Tovey, S. C.; Sun, Y.; Taylor, C. W. Rapid functional assays of intracellular $\mathrm{Ca}^{2+}$ channels. Nat. Protoc. 2006, 1, 259-263.

(96) Mills, S. J.; Potter, B. V. L. Synthesis of the enantiomers of myoinositol 1,2,4,5-tetrakisphosphate, a regioisomer of myo-inositol 1,3,4,5-tetrakisphosphate. J. Chem. Soc., Perkin Trans. 1 1997, 1279-1286. 